\title{
Stability Analysis of Shafts Used for Minewater Heat Recovery
}

\author{
Cheuklun Ng $\cdot$ Chrysothemis Paraskevopoulou (iD - Nicholas Shaw
}

Received: 23 November 2018/ Accepted: 7 June 2019/Published online: 13 June 2019

(C) The Author(s) 2019

\begin{abstract}
Traditional heating using non-renewable energy resources contributes up to $50 \%$ of current carbon emission level. Different sources of renewable energy are being exploited and developed to lower the carbon emission level for continuity of healthy living environment. It is found that thermal energy is stored in minewater flooding abandoned mines. The minewater can be extracted through newly drilled boreholes or existing mineshafts. To ensure successful and sustainable operation, mineshafts have to be structurally stable. When the mines are abandoned, the water level tends to recover. Some of the configurations of the minewater heat recovery may change the temperature of part of the shaft wall. This research aims to provide some insight on the stability of mineshafts for minewater heat recovery through numerical sensitivity analyses on: (a) water level, (b) temperature fluctuations. In the presented research work, rock masses with different properties have been analyzed. Change in temperature is found to mainly change the static Young's Modulus of intact rock and the joint roughness. However, the joint roughness is expressed indirectly using the Geological Strength Index, which has direct relationship with joint roughness and is used in stability analysis. It is found that an increase in water level reduces the integrity of the whole shaft.
\end{abstract}

C. Ng · C. Paraskevopoulou $(\bowtie) \cdot$ N. Shaw School of Earth and Environment, University of Leeds, Leeds, UK

e-mail: c.paraskevopoulou@leeds.ac.uk
The degrees of stability deterioration are different at different depths and depend on the in situ stress state. Findings of this analyses can be assist in making a decision on the selection of the appropriate configuration for minewater heat recovery.

Keywords Geothermal energy - Minewater heat recovery $\cdot$ Shaft stability $\cdot$ Numerical modelling

\section{Introduction}

A large amount of natural resources is being consumed for modern living. Sustainability becomes one of the most concerning issues for continuity of a healthy living environment. Different sources of renewable energy are being exploited and developed. One of them is thermal energy stored in minewater which can be extracted for heating. Cooling is, in fact, also possible by rejecting unwanted thermal energy into and storing it in minewater for later or other use. There are two main methods of extracting the minewater underground: through newly drilled boreholes down to the mine workings, or through existing mineshafts (Banks 2016; Banks et al. 2017). From the operation in Heerlen in the Netherlands is found to have $65 \%$ lower carbon emission level compared to traditional heating systems (Hiddes et al. 2016). Taking into consideration the past's UK legacy and heritage in 
coal mining (Fig. 1) there is a large potential in developing such technology. To sustain the minewater (i.e. thermal energy) extraction and/or re-injection, the continuous supply of minewater from mine workings into the shafts and integrity of the pumping equipment in the shafts are vital. Therefore, it leads to the necessity of structurally stable mineshafts.

Short-term stabilities of mineshafts during mining and after abandonment are well studied (Walton et al. 2018). Stability during aging of abandoned mineshafts is also discussed in some papers (Khan and Krige 2002). What is uncertain is the behaviour of the mineshafts when they are flooded and used for minewater heat recovery, especially when water with alteration in temperature from warmer to cooler is reinjected to the shafts. It is necessary to assess the integrity of shafts through sensitivity analyses with varying the mineshaft water level and temperature of the surrounding rock mass partially in the shaft wall. The main difference of the stability analysis of mineshafts in this research work from other ordinary analyses is the addition of temperature contrasts in rock mass brought by the re-injected minewater. In the current practices in the UK, temperature of maximum

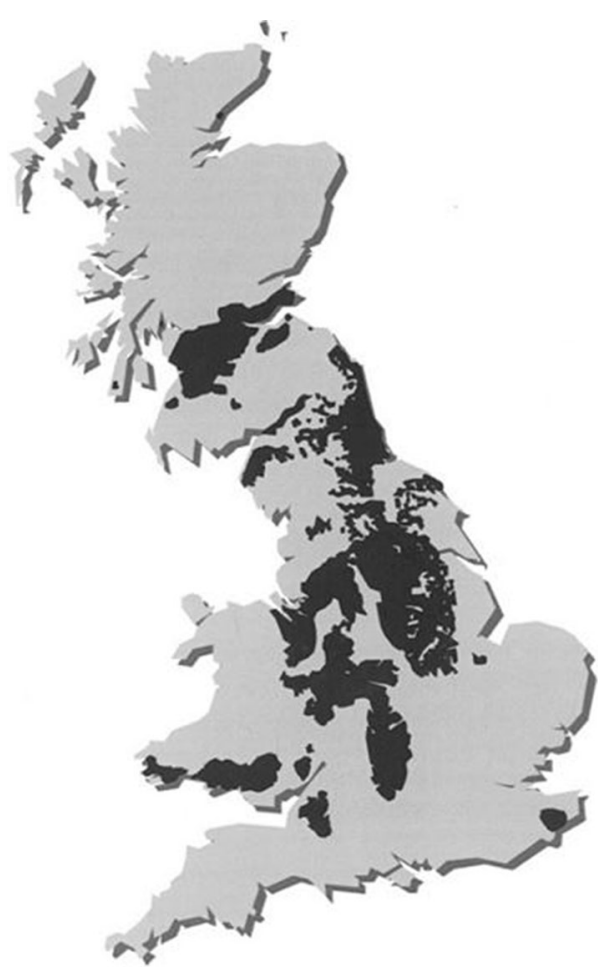

Fig. 1 Coal-mining regions in the UK (Parker 2011) about $6{ }^{\circ} \mathrm{C}$ is extracted from the minewater (Banks et al. 2017). As the usage of minewater for heating and cooling is expected to become more and more popular around the world with more advanced and efficient technology in the future, higher amount of energy may be extracted or re-injected. It is needed to know the behaviour of rock mass with varying temperature, and if there is a limit of temperature difference in energy extraction while ensuring the stability of the shaft.

This research aims to provide more insight on the feasibility of using existing mineshafts for minewater heat recovery from geotechnical engineering perspective by performing numerical stability analysis of mineshafts for the operation. The numerical sensitivity analyses presented herein cover different rock mass strengths by varying the quality of rock mass (i.e. Geological Strength Index (GSI)) and uniaxial compressive strength (UCS) of the intact rock, in different in situ stress states, in different water levels and different rock mass properties due to temperature change.

\section{Background}

\subsection{Underground Mining}

The success of operation of minewater heat recovery not only depends on the integrity of mineshafts, but also on the unblocked abandoned mine workings. It is therefore also important to understand the mine working layouts and the integrity of the corresponding mine workings. The layouts depend on the adopted mining methods, which are based on the outline of the ore body. They are designed to achieve high efficiency while trying to keep the rock mass stable. The two main mining methods for coal extraction are:

- Room and Pillar Mining: the hanging wall above the underground opened space (i.e. room) is supported by pillars. It is usually used for both shallow and deep low-dipping beds of limited thickness. The layout grid can be regular or random, although the latter case will make planning relatively difficult to keep the mine stable (Gertsch and Bullock 1998; Hustrulid and Bullock 2001).

- Longwall Mining: is used for mining thin-bedded deposits. The ore is extracted along a straight front 
of ca. 150-300 m wide with a longitudinal extension of ca. 1-3.5 km long. The stoping area just in front of the face is supported by the hydraulics for personnel and mining equipment, while the area behind is allowed to collapse and subside immediately, similar to retreat mining but much safer. This method has relatively high ore extraction ratio (Hustrulid and Bullock 2001). It requires a pre-existing network of haulage drifts prior to ore extraction.

\subsection{Minewater Heat Recovery}

\subsubsection{Principle and Operation}

During mining, the groundwater is pumped to create dry working condition. After abandonment, there will be three typical consequences (Banks et al. 2017):

- Dewatering is no longer needed. Groundwater will flow into the mine workings and start to flood the mine until it overflows at the surface through a mine opening.

- Water is kept being pumped, keeping the abandoned mine dry and preventing it from flowing to the working mines down-dip

- Water is kept being pumped to control the water level or recovery rate, avoiding uncontrolled outbreaks of water.

As per Banks (2012), the temperature of minewater is found to be as high as or higher than the local annual average soil temperature, with a rate of rise of $1-3{ }^{\circ} \mathrm{C}$ per $100 \mathrm{~m}$ increase in depth. Table 1 shows the power of the minewater corresponding to different pumping rates and temperature differences for energy extraction, using Eq. 1, while Table 2 shows the Coefficient of Performance (COP, a ratio of useful energy supplied to energy consumed by minewater heat recovery operation) at some operating locations.

Power $=\mathrm{Q} \times \rho_{\mathrm{w}} \times \mathrm{c}_{\mathrm{w}} \times \Delta \mathrm{T}$

where $\mathrm{Q}=$ Pumping Rate (L/day), $\rho_{\mathrm{w}}=$ Density of Water $=1 \mathrm{~kg} \mathrm{~L}^{-1}, \mathrm{c}_{\mathrm{w}}=$ Specific Heat Capacity of Water $=4190 \mathrm{~J} \mathrm{~kg}^{-1}{ }^{\circ} \mathrm{C}^{-1}, \Delta \mathrm{T}=$ Temperature difference for energy extraction $\left({ }^{\circ} \mathrm{C}\right)$.

It should be noted that in Subtropical and Tropical Zones, there are cases that the temperature of minewater is lower than the annual average soil temperature. Therefore the minewater has the potential to be used for both cooling and thermal energy storage, as long as the mine workings are remained intact and stable after abandonment (e.g. stable roomand-pillar mines). There are three methods of extracting the minewater: open-loop, closed-loop, and standing column systems described in the following subsections.

Open Loop Systems Open-loop systems refer to the systems with the pumped minewater directly passing through the heat exchangers (or heat pumps) for energy extraction or rejection (Banks 2016; Banks et al. 2017). There are mainly two types of open-loop systems, as shown in Fig. 2. The minewater used for energy release or absorption from the heat exchanger is either disposed or re-injected to the mine galleries through a reinjection borehole. Since the pumping only takes place in the mineshaft, no temperature is transferred within the surrounding rock mass. Openloop systems are being used in, for examples, National Coal Mining Museum of England (NCMME) at Caphouse, Yorkshire, UK and Barredo colliery at Mieres, Asturias, Northern Spain (Loredo et al. 2011; Ordóñez et al. 2012; Jardón et al. 2013; Burnside et al. 2016a; Banks 2016; Banks et al. 2017).

Closed Loop Systems In contrast to open-loop systems, minewater never flows into a heat exchanger in

Table 1 Power from minewater with different pumping rates and temperature differences

\begin{tabular}{lrll}
\hline$\Delta \mathrm{T}\left({ }^{\circ} \mathrm{C}\right)$ & $\mathrm{Q}(\mathrm{L} /$ day $)$ & Power $(\mathrm{kW})$ & Space heating power consumed per household in the UK $(\mathrm{kW})$ \\
\hline 2 & 200,000 & 19.4 & 1.26 (Palmer and Cooper 2013) \\
2 & $3,000,000$ & 291 & \\
5 & 200,000 & 48.5 & \\
5 & $3,000,000$ & 730 & \\
\hline
\end{tabular}


Table 2 COP examples in some operating locations (Hiddes et al. 2016; Banks et al. 2017)

\begin{tabular}{ll}
\hline Location & COP \\
\hline National Coal Mining Museum for England, UK (open-loop system) & $3.5-4.0$ \\
Markham No.3 Shaft, Derbyshire, UK (standing column system) & 1.9 \\
Heerlen Colliery, Netherlands (open-loop system) & 7 \\
\hline
\end{tabular}

(a)

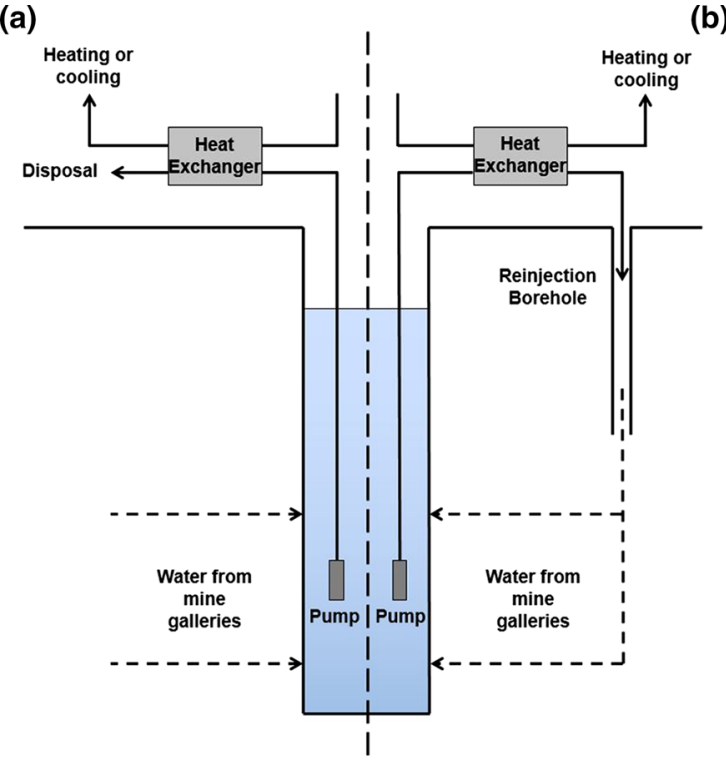

Fig. 2 Open-loop systems with thermal energy released or absorbed minewater a disposed, or $\mathbf{b}$ re-injected. Modified after Banks et al. (2017)

closed-loop systems (Banks et al. 2017). The heat exchanger is either located (typically a steel radiator or a loop of polythene pipe) inside the mineshaft, or inside the minewater treatment pond to undergo heat exchange with minewater, as shown in Fig. 3. The submerged heat exchanger in mineshaft may alter the temperature of the rock on part of the shaft wall.

Standing Column Systems Pumped minewater can also be re-injected into mineshaft at a different depth after undergoing heat exchange. Such configuration is called standing column (Athresh et al. 2015; Banks 2016; Banks et al. 2017). The reinjected water typically either flows downward or upward towards the pump or laterally back into mine galleries. When the minewater is slowly flowing towards the pump in mineshaft, it gains or loses thermal energy through heat exchange with the rock on shaft wall, as shown in Fig. 4. As thermal energy is released or absorbed minewater is re-injected into the shaft, a temperature

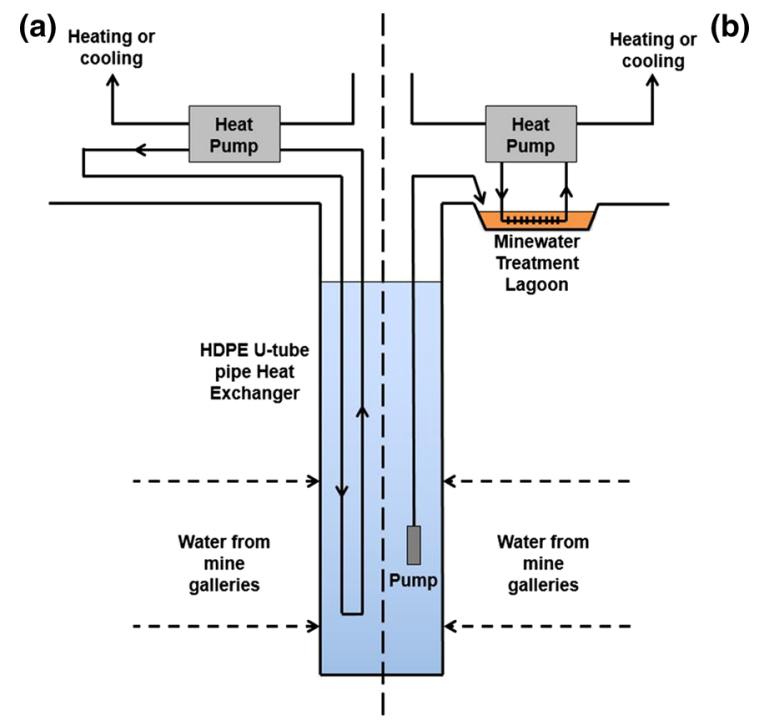

Fig. 3 Closed-loop systems with heat exchange undergone in a mineshaft, or $\mathbf{b}$ minewater treatment lagoon. Modified after Banks et al. (2017)

difference occurs on part of the shaft wall. Such system is being used at Markham Colliery No.3 Shaft near Bolsover, Derbyshire, UK (Athresh et al. 2015; Banks 2016; Banks et al. 2017).

\subsubsection{Past Studies and Previous Research}

There are a few studies on the potential thermal resource in different abandoned coal mine workings (Macnab 2011). There are also several collieries, like the Caphouse Colliery in Yorkshire, the Markham Colliery in Derbyshire in the UK, and the Heerlen Colliery in the Netherlands, currently serve as thermal energy providers. These studies concluded that the followings have to be considered when examining the minewater potential as thermal resource:

- Risk of Thermal Feedback: it is the phenomenon where the re-injected thermally spent minewater 


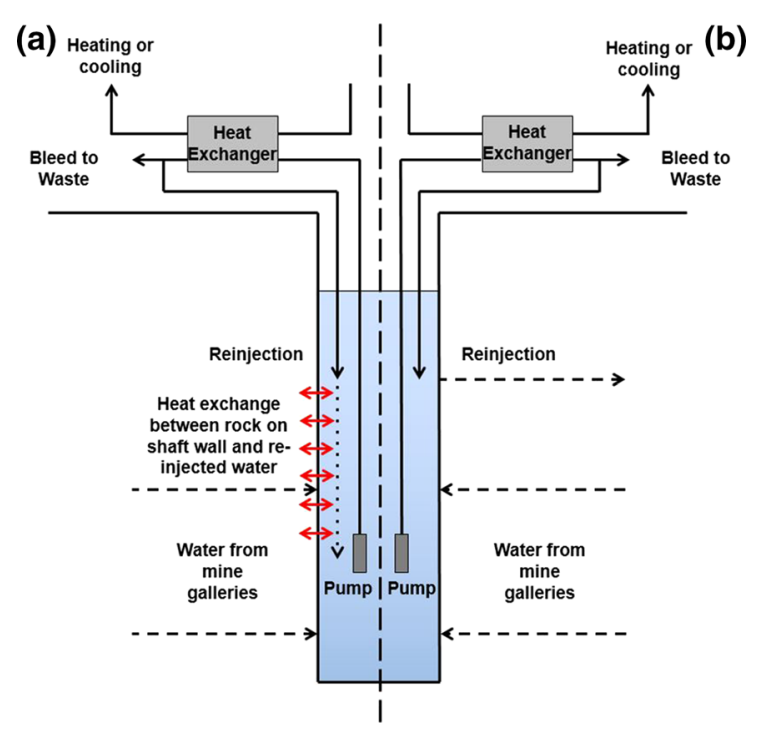

Fig. 4 Standing column systems with re-injected minewater a flowing downward (or upward) and undergoing heat exchange with the rock on wall in mineshaft, or $\mathbf{b}$ flowing back into mine galleries (after Banks et al. 2017)

reaches the abstraction well too fast, reducing the efficiency of the operation.

- Regional Hydrogeology: it is necessary to understand the hydrogeological properties, how the water flows and its flow rate in the underground environment in order to decide the sustainability and long-term efficiency of the operation. Due to mine workings, the natural hydrology may be severely altered, like connecting two catchments by the mine roadways (Foster et al. 2005). It is also vital to find out whether the hydrological conditions changes over time, and after the installation of the operation.

- Temperature of Minewater: it is obvious that the degree and the stability of temperature (constant) of minewater throughout the years is vital to the efficiency of the operation.

Studies by the UK Coal Authority have already shown that the abandoned mines in Glasgow, Bates, Woolley, Strafford, Dawdon, etc. have the potential to be used as thermal resources (Macnab 2011; Parker 2011). While the above is important, the integrity of the shaft is also essential to achieve an efficient and successful operation.

\subsection{Structural Stability of Shafts}

\subsubsection{Failure Modes and Deformation of Mineshafts}

Lecomte et al. (2014) reports failures that have occurred in mineshafts around Europe. Generally, the main reasons of these failures vary. However, some of these reported failures are due to backfilled material and surface instabilities. It should be noted that in the presented work the shafts are intended to be used for minewater heat recovery and only the potential failure modes during such operation are discussed.

Failure or Spalling of Shaft Lining Shaft lining is the material supporting the wall of the shaft and preventing it from collapsing. The materials are mainly bricks, stone blocks, mortar, concrete, cast iron and/or steel.
Fig. 5 Typical deformation modes of shaft with anisotropic stresses: a left, dumb-bell shape (after Vakili et al. 2014); b right, eye shape (after Martin 1997)
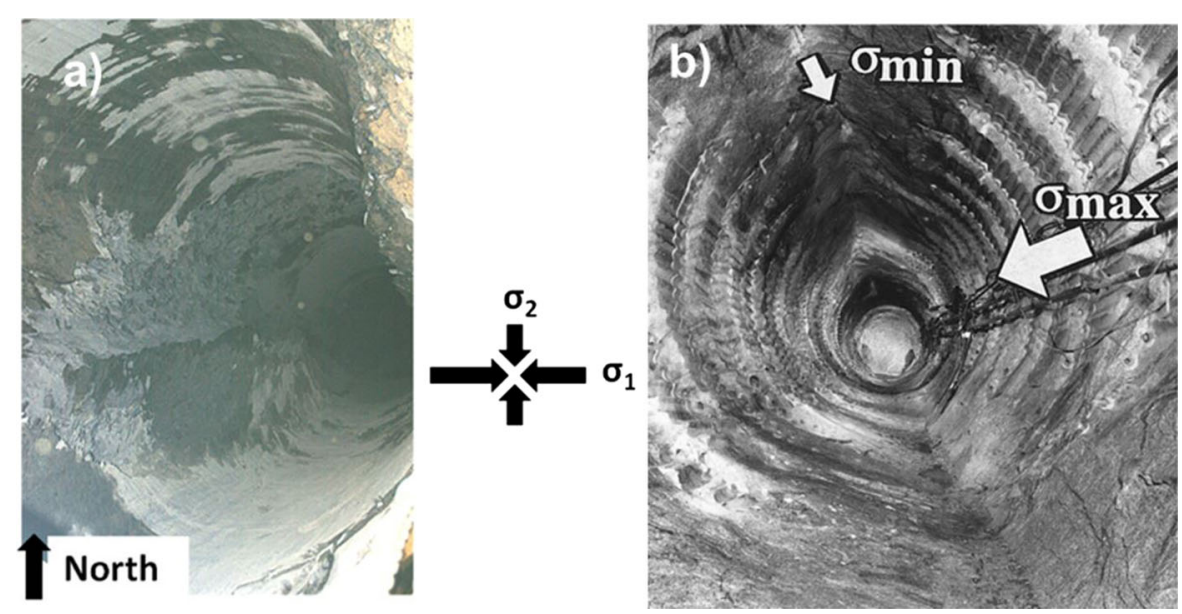
Table 3 Summary of different numerical models performed in this analysis

\begin{tabular}{llrll}
\hline Rock mass & $\mathrm{E}_{\mathrm{i}}(\mathrm{GPa})$ & $\mathrm{UCS}_{\mathrm{i}}(\mathrm{MPa})$ & $\mathrm{GSI} ;$ corresponding $\gamma\left(\mathrm{kN} / \mathrm{m}^{3}\right)$ & k-ratio \\
\hline 1 & 10 & 50 & $25 ; 24$ & 0.5 \\
2 & 70 & 50 & $25 ; 24$ & 0.5 \\
3 & 10 & 200 & $25 ; 24$ & 0.5 \\
4 & 70 & 200 & $25 ; 24$ & 0.5 \\
5 & 10 & 50 & $75 ; 26$ & 0.5 \\
6 & 70 & 50 & $75 ; 26$ & 0.5 \\
7 & 10 & 200 & $75 ; 26$ & 0.5 \\
8 & 70 & 200 & $75 ; 26$ & 0.5 \\
9 & 10 & 50 & $25 ; 24$ & 2 \\
10 & 70 & 50 & $25 ; 24$ & 2 \\
11 & 10 & 200 & $25 ; 24$ & 2 \\
12 & 70 & 200 & $25 ; 24$ & 2 \\
13 & 10 & 50 & $75 ; 26$ & 2 \\
14 & 70 & 50 & $75 ; 26$ & 2 \\
15 & 10 & 200 & $75 ; 26$ & 2 \\
16 & 70 & 200 & $75 ; 26$ & 2 \\
\hline
\end{tabular}

However, as the lining material is weathered after the mine is abandoned, its strength degrades with time. Hence it deforms and eventually collapses. One shaft collapse example due to deterioration of shaft lining is the Coal Shaft V, Knurow-Szczyglowice colliery in Poland in 2008. This shaft was initially sunk in 1972 and further sunk to $632.05 \mathrm{~m}$ in 1986, with a diameter of $6 \mathrm{~m}$ and brick and concrete lining and the water inflow was below $35 \mathrm{~L} / \mathrm{min}$ (Lecomte et al. 2014).

Yang et al. (2017) performed an experiment on three lining materials (brick, mortar and concrete) submerging in potable water, minewater and an aggressive version of minewater with $\mathrm{pH}$ of 7.0, 6.0 and 1.3 respectively for 48 weeks. The aggressive version of minewater was used as an insight for longterm evolution of the materials. All materials showed mass loss in the aggressive solution, especially for mortar. While shear strength of brick significantly lowered, mortar had its static Young's modulus reduced instead. For concrete, the UCSi, static Young's Modulus and shear strength decreased less significantly. As the shafts used for minewater heat recovery, commonly are not maintained after abandonment of mines, it is assumed in this analysis that the shaft lining is expected to contribute the minimum to the support of the shaft wall as if the shafts were constructed by bricks.
Failure Due to Water Effect Rise in groundwater level or infiltration of rainwater can lead to inflow of groundwater into the shaft which can rupture the shaft lining if there is sufficient inflow pressure. This concept is investigated in this analysis. Moreover, rise in pore water pressure lowers the effective stress in the rock mass, leading to shear failure. One representative example is the collapse of a $10 \mathrm{~m}$ wide shaft located in Tirphil, New Tredegar, UK, where an adit, at the lowest free drainage for the Brithdir Seam was connected to the shaft (Lecomte et al. 2014).

Failure Due to Particular Geological Formations The presence of geological formation that is relatively weak, soluble rock, or soil susceptible to liquefaction destabilizes the shaft wall or lining and causes failure. Coal Shaft V in Pniowek colliery and Coal shaft Boles Law in Bobrek-centum colliery in Poland collapsed because of the inrush of quicksand layer into shaft (Lecomte et al. 2014; Salmon et al. 2015). However, as the existence of such geological formation is not the common case, this failure mode is not considered to be investigated in this research work.

Deformation Due to Anisotropic Horizontal Stresses Due to anisotropy in horizontal axis, stresses divert to and/or concentrate at certain areas of the circular shaft while deforming it. There are two usual types of deformation shown with major and minor principal stresses in Fig. 5. However, as the aim of this research 

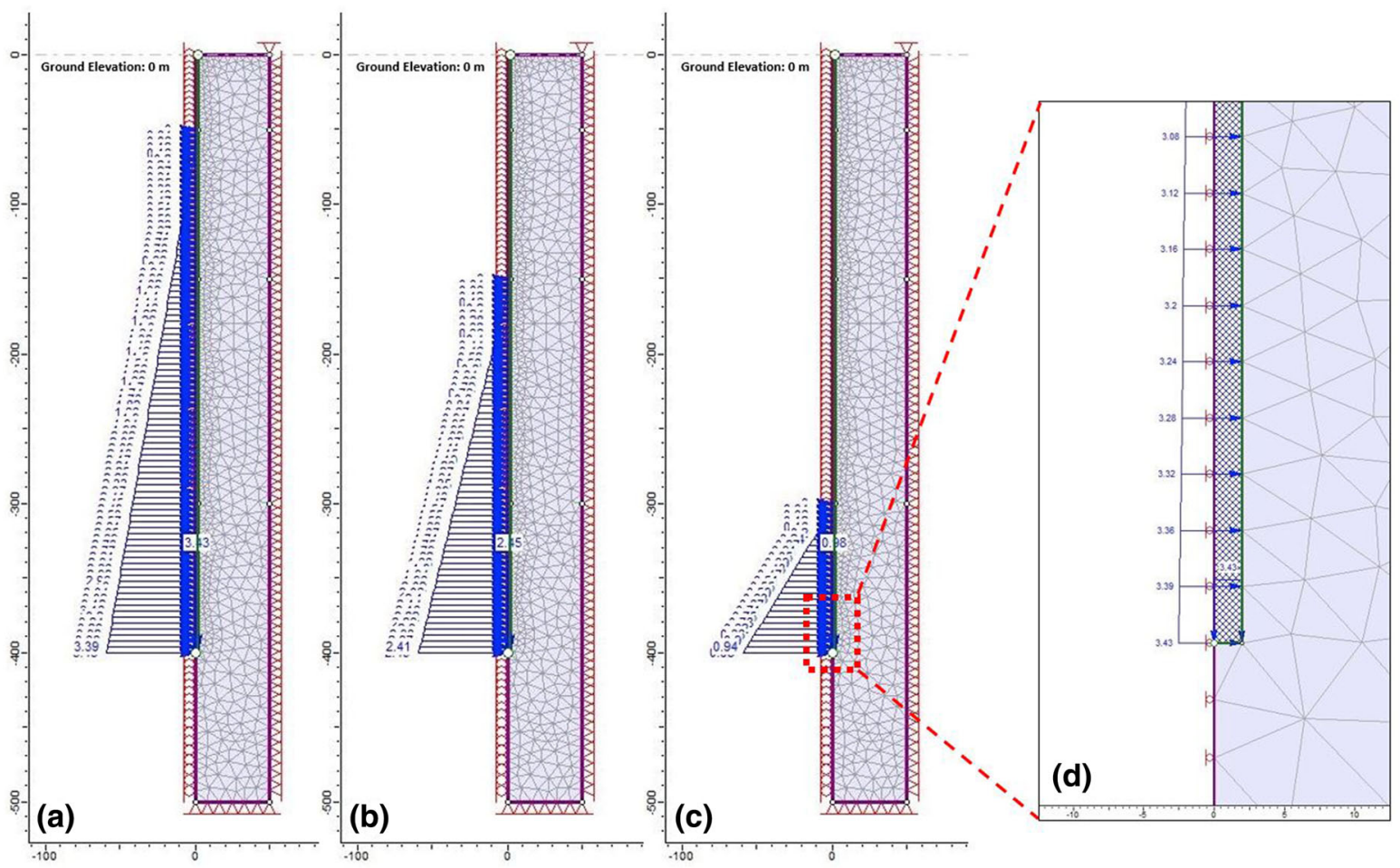

Fig. 6 Models with water level in mineshaft at a left, $-50 \mathrm{~m}$, b middle, $-150 \mathrm{~m}$, $\mathbf{c}$ right, $-300 \mathrm{~m}$, $\mathbf{d}$ close up to bottom of shaft

work is to investigate the shaft stability during the operation of minewater heat recovery, the latter is not be considered.

Failure Due to Gas Release Harmful and potentially explosive gases may be present in old mines. These gases may concentrate in mine cavities and/or chemically weather the rock. Shaft failure due to gas release is anticipated when there is enough air pressure between the shaft and the cavities, or a sudden rise in the groundwater table pushing out the gases to surface, as observed in Coal shaft Barrois at Creutzwald in France (Lagny 2014; Lecomte et al. 2014). This failure mode is not herein taken under consideration.

In summation, the work presented herein assumes that the shaft lining of the abandoned mine behaves in a similar manner as a brick wall that has lost most of its strength over time, with very poor geotechnical characteristics. In addition, this work investigates the shaft failure resulting from the water effect and more specifically the changes in the groundwater level (due to the heat recovery operations) that can contribute in the rupture of the lining and any other failure mode is considered to be out of scope.

\section{Methodology and Numerical Analysis}

A series of numerical axisymmetric analyses using RS $^{2}$ (Rocscience) software Finite Element Method (FEM) is performed and discussed in this section.

\subsection{Axisymmetric Analysis}

\subsubsection{Model Assumptions and Input Parameters}

Axisymmetric analysis is undertaken by making the following assumptions. The surrounding rock-mass' behaviour is considered to be elasto-plastic and the (Generalized) Hoek-Brown criterion is used as a continuum model. A range of the Geological Strength Index (GSI, Hoek and Marinos 2000) and different values of UCS are also considered to represent different rock masses from strong to weak (or weathered) conditions (Sattler and Paraskevopoulou 2019). More specifically, high and low UCS of intact 


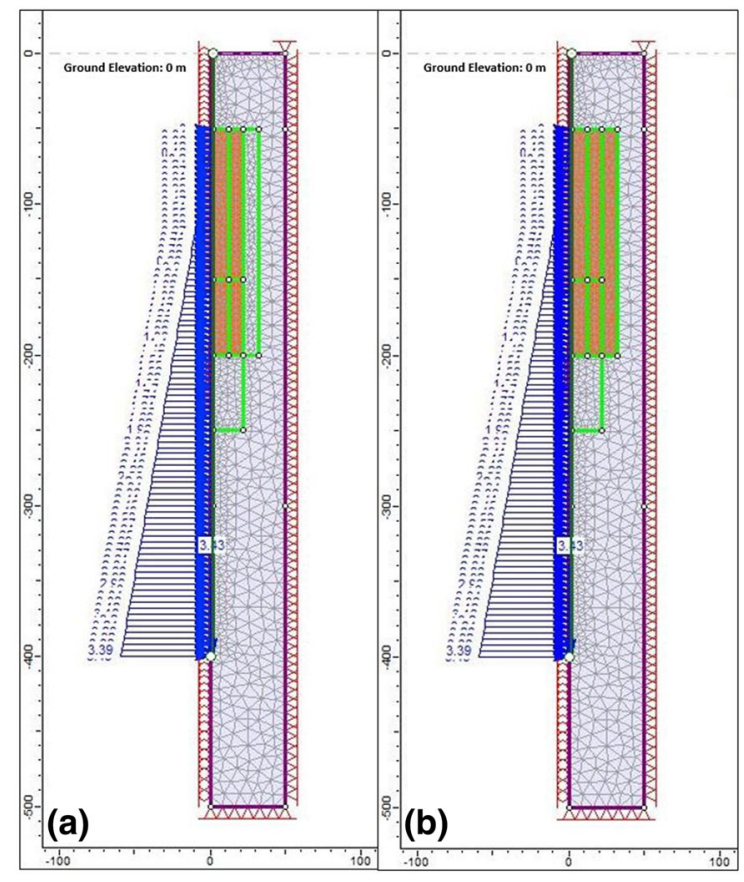

Fig. 7 a Model used in sensitivity analyses of Changing Static Young's Modulus or GSI of Part of Shaft Wall (orange region: $150 \mathrm{~m}$ long and $20 \mathrm{~m}$ thick); b example of model used in sensitivity analyses of dimension of the part of shaft wall with different temperature (orange region: $150 \mathrm{~m}$ long and $30 \mathrm{~m}$ thick)

rock $(\mathrm{UCSi}=\sigma c i=200 \mathrm{MPa}$ and $50 \mathrm{MPa})$ and GSI (75 and 25) are used to confirm if there is a general trend applied to different rock masses in this the sensitivity analysis. There is no clear trend capturing the thermal effect with the USCi in the literature, apart from Woodman et al. 2018 where they examined thermal effect on discontinuity strength on Thornhill Sandstone Further research is required, UCSi of intact rock is assumed to be reduced.

Table 3 Summarizes the analysis and the various models performed.

It should be noted that depending on the heat production system the produced water after the heat exchanger is re-injected back into the mineshaft(s) at potentially various levels. This maybe be the same as the heat production shaft where the fluid must then can re-equilibrate with the temperature of the surrounding rock and shaft lining. The re-heated heat fluid is then available to be produced again to supply heat to the exchanger. The balance between heat offtake and reheating is influenced by both the shaft rock and the lining thermal transmittance and the heat demand.
Alternatively, there could be a cooling of the production water. Most systems will have peaks in heat demand in winter and less off-take in summer resulting in a thermal cycling. If the return water is re-injected into a different shaft the temperature variation may be reduced in the production shaft allowing smoother operation, the cooler water/more viscous water would displace warmer water to the production shaft. In this paper, the numerical analysis indirectly simulates this process which is basically a temperature cycling, almost thermal fatigue loading. Moreover, the selection of strength parameters aims to cover a wide range of different rock types. Hoek (2006) states that the typical $\sigma c i$ (or UCSi) of different rock types typically ranges from $5 \mathrm{MPa}$ to more than $250 \mathrm{MPa}$ and with increasing weathering grade, $\sigma \mathrm{ci}$ and GSI will generally reduce (decreasing at different rates in different rock types). Failure occurs when the stresses exceed peak strength. However, some materials have residual strengths and allow the materials to "hold on" after failure takes place (when the postfailure stresses do not exceed the residual strengths). One way to parameterise such phenomenon is using peak and residual GSIs in the Generalized HoekBrown Failure Criterion. GSI depends on the structure of the rock mass and the surface condition of the joints. According to Cai et al. (2007), the residual GSI can be estimated by determining the block sizes and the roughness of joints after failure. In general, the higher the peak GSI is, the larger decrease in number in residual GSI will be.

More specifically, the following conditions have been considered.

In-Situ Stress The stress on the rock mass is assumed to be solely applied by the overburden in the analysis. The in situ-stress state of a point depends on unit weight of the overburden, depth of the point and the k-ratio. In general, it is more sensible to use slightly lower unit weight for low GSI, which also has direct inverse-relation with weathering grade (Hoek 2006), i.e. $\gamma=26 \mathrm{kN} / \mathrm{m}^{3}$ for GSI $=75$ and $\gamma=24 \mathrm{kN} / \mathrm{m}^{3}$ for $\mathrm{GSI}=25$. The change in unit weight due to change in temperature is extremely small to a scale that cannot be varied in the input parameter section and such change is neglected. At shallow depths k-ratio varies significantly, two k-ratios (0.5 and 2.0) have been considered and assumed to be constant with changing depth. 
Table 4 Different Ei and GSI considered in the analysis (blue shades correspond to lower temperature in orange region while orange shades correspond to higher temperature in orange region)

\begin{tabular}{|c|c|c|c|}
\hline $\mathrm{E}_{\mathrm{i}}$ in orange region $(\mathrm{GPa})$ & $\mathrm{E}_{\mathrm{i}}$ in surroundings $(\mathrm{GPa})$ & GSI in orange region & GSI in surrounding rock mass \\
\hline \multicolumn{4}{|l|}{ Rock masses } \\
\hline 9.5 & 10 & 25 & 25 \\
\hline 9.75 & 10 & 25 & 25 \\
\hline 10.25 & 10 & 25 & 25 \\
\hline 10.5 & 10 & 25 & 25 \\
\hline 9.5 & 10 & 75 & 75 \\
\hline 9.75 & 10 & 75 & 75 \\
\hline 10.25 & 10 & 75 & 75 \\
\hline 10.5 & 10 & 75 & 75 \\
\hline 66.5 & 70 & 25 & 25 \\
\hline 68.25 & 70 & 25 & 25 \\
\hline 71.75 & 70 & 25 & 25 \\
\hline 73.5 & 70 & 25 & 25 \\
\hline 66.5 & 70 & 75 & 75 \\
\hline 68.25 & 70 & 75 & 75 \\
\hline 71.75 & 70 & 75 & 75 \\
\hline 73.5 & 70 & 75 & 75 \\
\hline 10 & 10 & 23 & 25 \\
\hline 10 & 10 & 24 & 25 \\
\hline 10 & 10 & 26 & 25 \\
\hline 10 & 10 & 27 & 25 \\
\hline 70 & 70 & 23 & 25 \\
\hline 70 & 70 & 24 & 25 \\
\hline 70 & 70 & 26 & 25 \\
\hline 70 & 70 & 27 & 25 \\
\hline 10 & 10 & 73 & 75 \\
\hline 10 & 10 & 74 & 75 \\
\hline 10 & 10 & 76 & 75 \\
\hline 10 & 10 & 77 & 75 \\
\hline 70 & 70 & 73 & 75 \\
\hline 70 & 70 & 74 & 75 \\
\hline 70 & 70 & 76 & 75 \\
\hline 70 & 70 & 77 & 75 \\
\hline
\end{tabular}

Stiffness of Rock Mass Typical static Young's Moduli values of different rock types lie between ca. 1 and $80 \mathrm{GPa}$ (Brotons et al. 2015), while the Poisson's Ratios typically lie between ca. 0.1 and 0.4 (Gercek 2007).

Wang et al. (2015) performed an experiment to find out the influence of temperature in the range from ca.
20 to $80{ }^{\circ} \mathrm{C}$ in water-rock interactions on rock joint surface. In general, the roughness increases as the temperature increases, but the rate of increase varies at different temperatures.

Suknev (2016) has performed a laboratory test on dry limestone and siltstone to determine the relationship of static Young's Modulus and Poisson's Ratio with temperature in the range from -40 to $20{ }^{\circ} \mathrm{C}$. It is 

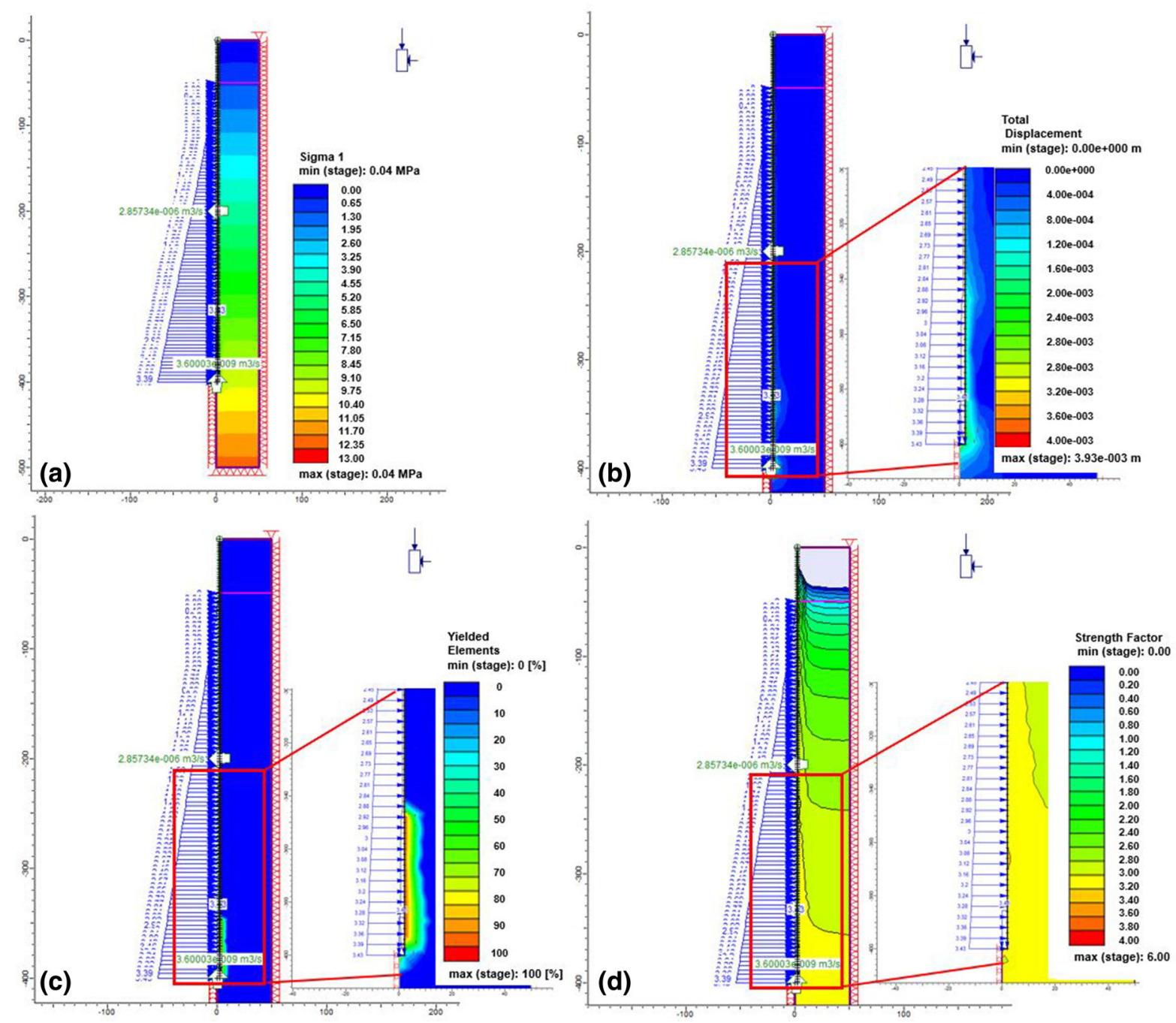

Fig. 8 Results of elasto-plastic analysis a sigma 1; b total displacement; c yielded elements; $\mathbf{d}$ strength factor result of elastic analysis in water level $=-50 \mathrm{~m}, \mathrm{GSI}=25, \gamma=24 \mathrm{kN} /$

found that the static Young's Modulus decreases linearly with increasing temperature while the Poisson's Ratio remains unchanged. Kamoshida et al. (2018) looked at both dry and wet samples of tuff and sandstone in the temperature range from -170 to $20{ }^{\circ} \mathrm{C}$. The dry sample findings agree with Suknev's conclusion. However, while the static Young's Moduli of wet samples of tuff decrease non-linearly with increasing temperature, those of sandstone fluctuate instead. The Poisson's Ratios of wet samples of both rock types fluctuate with increasing temperature. The UCSi of both wet and dry samples of tuff decrease with temperature, while those of sandstone remained

$\mathrm{m}^{3}$, k-ratio $=0.5, \mathrm{UCSi}=50 \mathrm{MPaa}$ and $\mathrm{Ei}=10 \mathrm{GPa}$ (lower figures shows zoomed bottom of shaft with red arrows representing total displacement of a scale factor of 1000)

constant. The number of data points is not enough to draw a solid conclusion on how the rock properties change with small varying temperature. However, a sensitivity analysis of static Young's Modulus and parameter(s) related to rock joint roughness, as Wang et al. (2015) suggested, (i.e. indirectly GSI) for calculation of strength of rockmass can be performed. Based on the afore-mentioned, in this analysis the Static Young's Modulus is assumed to change with temperature. Both high and low Moduli of intact rock $\left(E_{i}=70 \mathrm{GPa}\right.$ and $\left.10 \mathrm{GPa}\right)$ are analyzed and a Poisson's ratio of 0.25 is considered. The Modulus of the rockmass $\left(\mathrm{E}_{\mathrm{rm}}\right)$ is then calculated. 
Fig. 9 Sigma 1 for a $\mathrm{UCSi}=50 \mathrm{MPaa}$ and k-ratio $=0.5$; b UCSi $=200 \mathrm{MPa}$ and k-ratio $=0.5$; c UCSi $=50 \mathrm{MPa}$ and k-ratio $=2.0$; d UCSi $=200 \mathrm{MPa}$ and $\mathrm{k}$-ratio $=2.0$
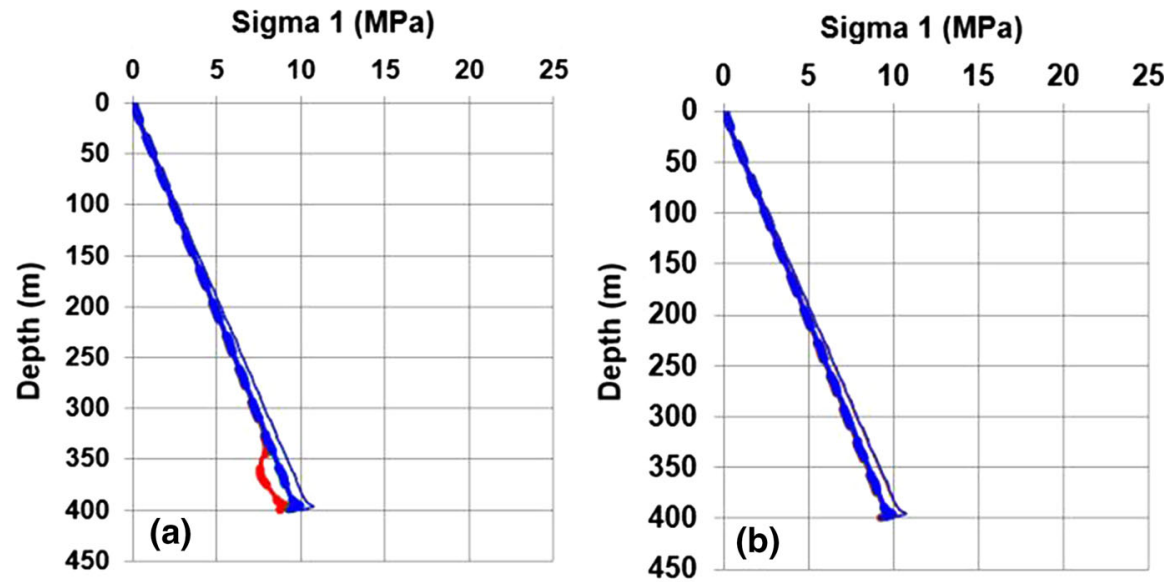

Sigma 1 (MPa)

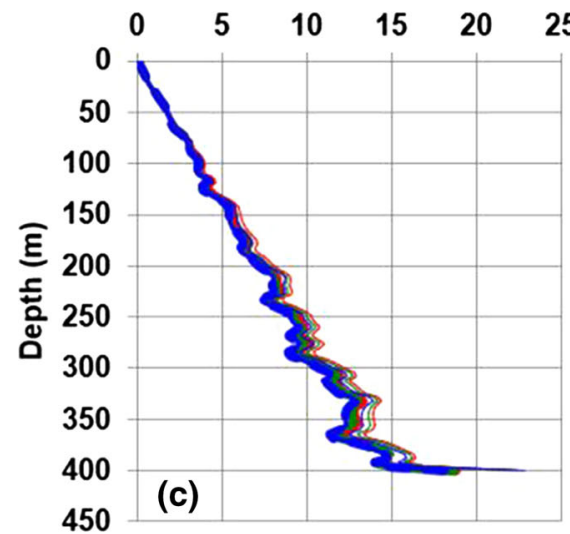

$W L=-50 \mathrm{~m}, E=10 \mathrm{GPa}, \mathrm{GSI}=25(\mathrm{Y}=24 \mathrm{kN} / \mathrm{m} 3)$

$W \mathrm{WL}=-50 \mathrm{~m}, \mathrm{E}=70 \mathrm{GPa}, \mathrm{GSI}=25(\mathrm{Y}=24 \mathrm{kN} / \mathrm{m3})$

$W L=-150 \mathrm{~m}, E=10 \mathrm{GPa}, \mathrm{GSI}=25(\mathrm{Y}=24 \mathrm{kN} / \mathrm{m} 3)$

-WL=-150m, E=70GPa, GSI=25 (Y=24kN/m3)

$W L=-300 \mathrm{~m}, E=10 \mathrm{GPa}, \mathrm{GSI}=25(\mathrm{Y}=24 \mathrm{kN} / \mathrm{m} 3)$

$-W L=-300 \mathrm{~m}, E=70 G P a, G S I=25(Y=24 \mathrm{kN} / \mathrm{m} 3)$
$W L=-50 \mathrm{~m}, E=10 \mathrm{GPa}, \mathrm{GSI}=75(\mathrm{Y}=26 \mathrm{kN} / \mathrm{m} 3)$ $W L=-50 \mathrm{~m}, E=70 G \mathrm{~Pa}, \mathrm{GSI}=75(\mathrm{Y}=26 \mathrm{kN} / \mathrm{m} 3)$ $W L=-150 \mathrm{~m}, E=10 \mathrm{GPa}, G S I=75(Y=26 \mathrm{kN} / \mathrm{m} 3)$ $W L=-150 \mathrm{~m}, E=70 G \mathrm{~Pa}, \mathrm{GSI}=75(\mathrm{Y}=26 \mathrm{kN} / \mathrm{m} 3)$ $W L=300 \mathrm{~m}, E=10 \mathrm{GPa}, \mathrm{GSI}=75(\mathrm{Y}=26 \mathrm{kN} / \mathrm{m} 3)$

- WL $=-300 \mathrm{~m}, E=70 G \mathrm{~Pa}, \mathrm{GSI}=75(\mathrm{Y}=26 \mathrm{kN} / \mathrm{m} 3)$

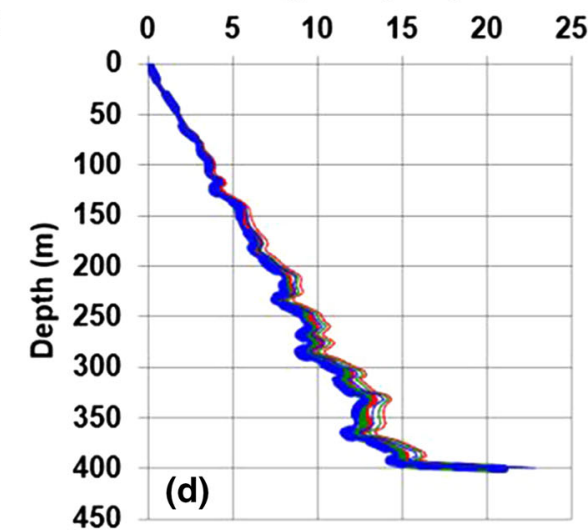

The authors do note that this approach pseudosimulates the temperature changes and further research needs to be done to complement this methodology as this work contributes towards it. It should be also stated that some combinations between $\mathrm{E}$ and UCSi (low values of $\mathrm{E}$ with high values of UCSi) might not be realistic and when deriving conclusions this should be excluded.

Groundwater Pore water pressure directly controls the effective stresses of different rock masses consequently their stabilities. Three different water levels $(-50 \mathrm{~m},-150 \mathrm{~m}$ and $-300 \mathrm{~m})$ are analyzed. The hydraulic gradient of groundwater towards the shaft is set as $6 \times 10^{-4}$ according to Younger (2016) who studied the hydrogeological consequences of coalfield closure. Although change in hydraulic gradient will induce different stresses, the range of hydraulic gradient is very small. The conductivity only controls the flow rate but not stresses a value of $10^{-6} \mathrm{~m} / \mathrm{s}$ is considered.

The induced water flow by pumping and reinjection is also considered, but its effect to shaft stability is determined as negligible. This is because the hydraulic gradient and velocity of such induced flow is found to be extremely low. The calculation is based fluid mechanics theory. When minewater in shaft is pumped, a hydraulic gradient is induced throughout the shaft such that water flows towards the pump. By treating the mineshaft as a large pipe, along with the consideration of different viscosities and 
Fig. 10 Total displacement for $\mathbf{a} \mathrm{UCSi}=50 \mathrm{MPa}$ and k-ratio $=0.5$;

b UCSi $=200 \mathrm{MPa}$ and

k-ratio $=0.5$;

c UCSi $=50 \mathrm{MPa}$ and

k-ratio $=2.0$;

d UCSi $=200 \mathrm{MPa}$ and

k-ratio $=2.0$

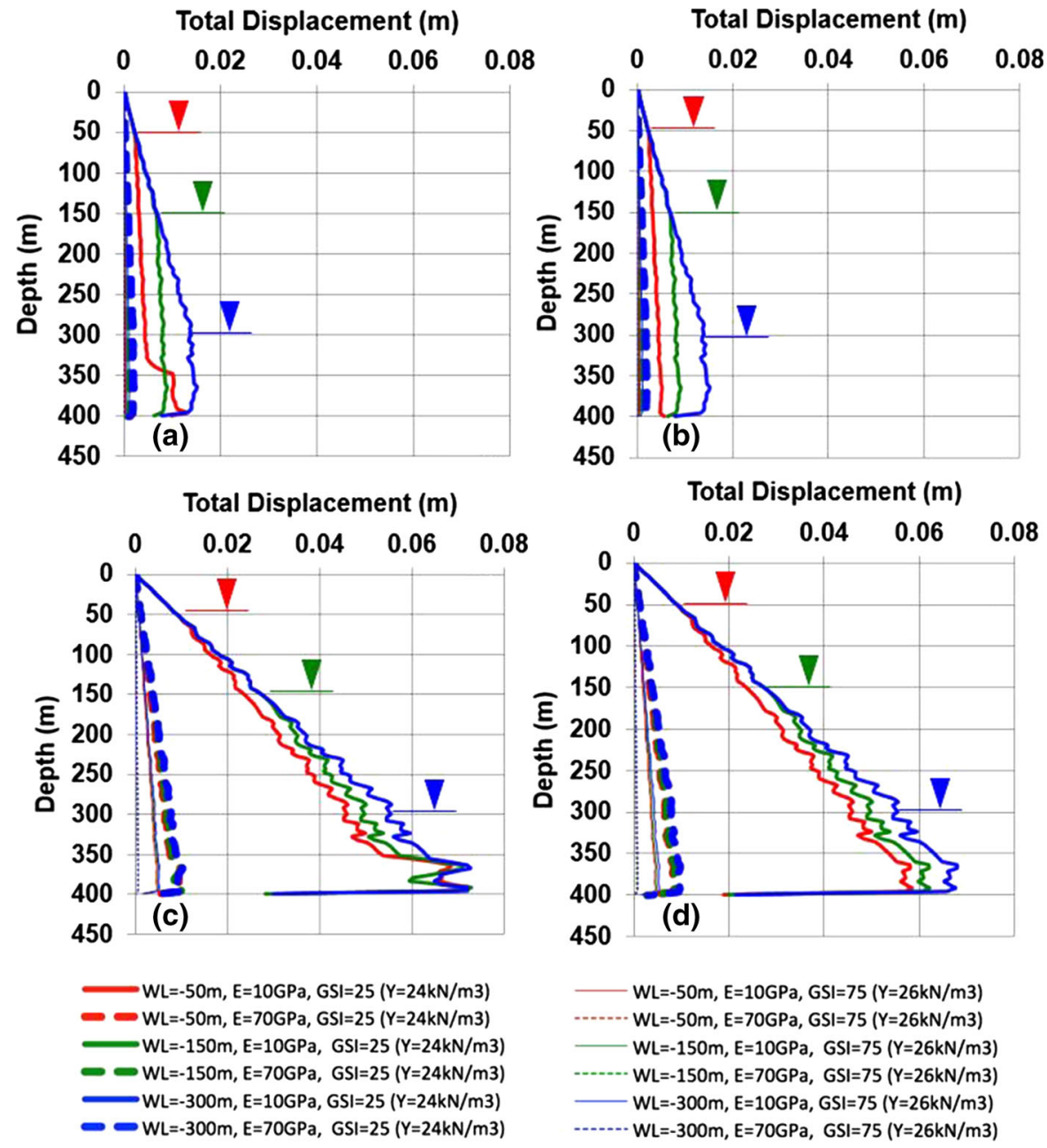

water levels at different temperatures in the range from 5 to $35{ }^{\circ} \mathrm{C}$, the hydraulic gradient induced with pumping rate of $300 \mathrm{~L} / \mathrm{s}$ in a shaft of $3 \mathrm{~m}$ in diameter is only ca. $10^{-8}-10^{-9}$ (Domenico and Schwartz 1998) which can be assumed negligible.

\subsection{Sensitivity Analyses and Numerical Modelling Sequence}

The numerical models simulate a shaft that has already been excavated and flooded at the same time in one stage to represent the real problem as this study focuses on the effect of temperature and water table level changes. The shaft is basically flooded as the aquifer rebounds to its original hydrostatic level thereafter the effects are basically temperature cycling-almost low temperature thermal fatigue.
More specifically, a sensitivity analysis of static Young's Modulus and parameter(s) related to rock joint roughness, as Wang et al. (2015) suggested, (i.e. indirectly GSI) for calculation of strength of rockmass is performed. Four main analyses are considered: changing water level, changing static Young's Modulus of the shaft wall, changing GSI (representing changing joint roughness) of the shaft wall, and changing dimension of the shaft wall. Once the quantitative relationships: (a) between temperature and static Young's Modulus of wet rock samples and (b) between the new statistical parameters and GSI are established, the numerical models are computed.

The results of the models runs are expressed and displayed: in major principal stress (Sigma 1) and total displacement in plastic analysis and strength factor in elastic analysis due to certain rate of change in water 
Fig. 11 Strength factor for a $\mathrm{UCSi}=50 \mathrm{MPa}$ and

k-ratio $=0.5$;

b $\mathrm{UCSi}=200 \mathrm{MPa}$ and

k-ratio $=0.5$;

c $\mathrm{UCSi}=50 \mathrm{MPa}$ and

k-ratio $=2.0$

d UCSi $=200 \mathrm{MPa}$ and

$\mathrm{k}$-ratio $=2.0$
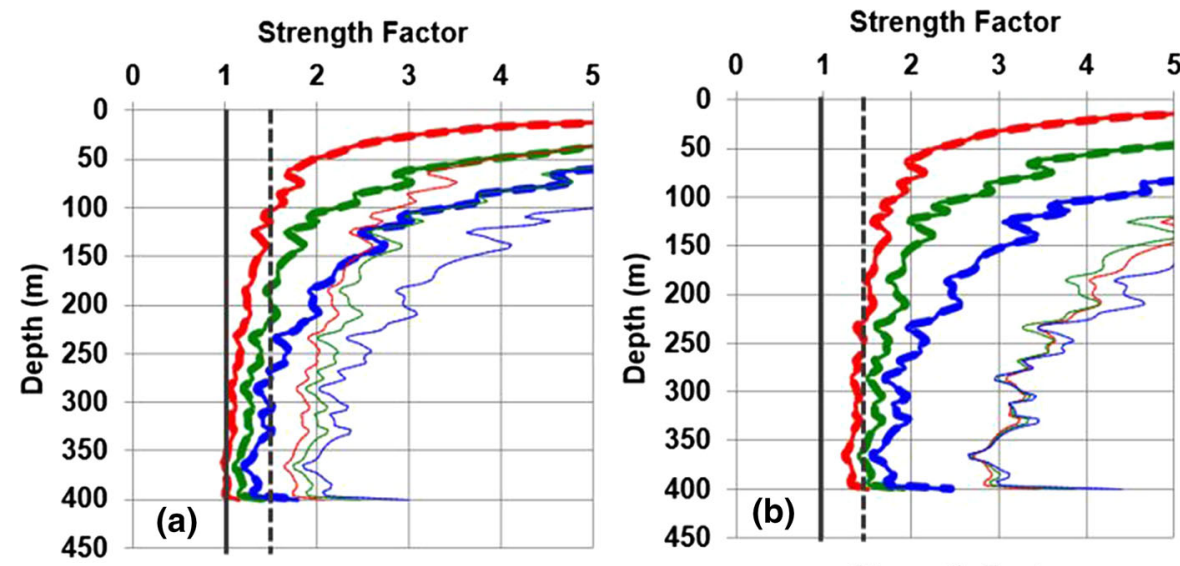

Strength Factor

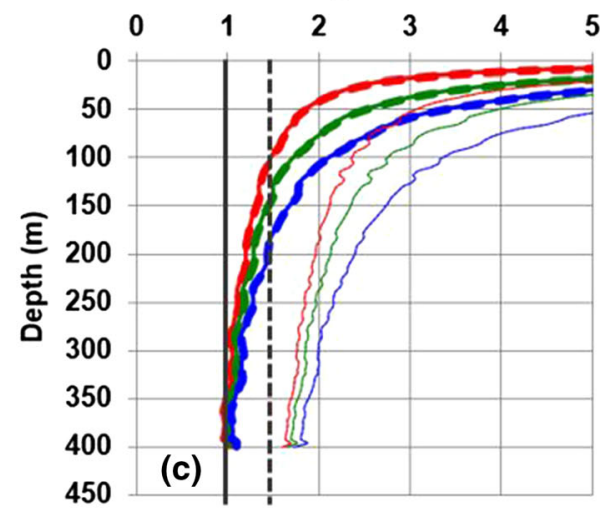

5

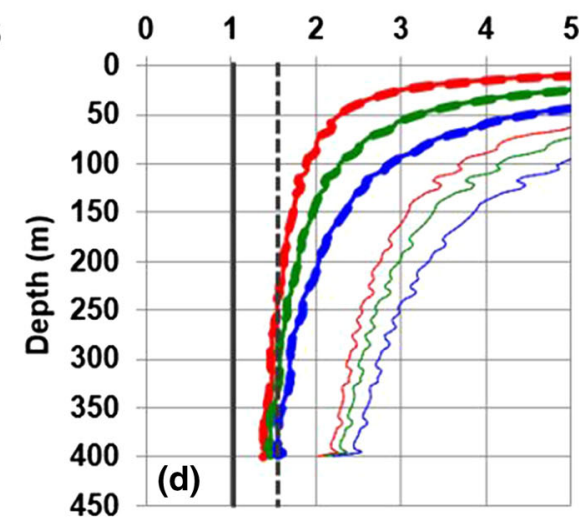

450

- WL=-50m, E=10GPa, GSI=75 (Y=26kN/m3)

--- $W L=-50 \mathrm{~m}, E=70 \mathrm{GPa}, \mathrm{GSI}=75(Y=26 \mathrm{kN} / \mathrm{m} 3)$

- $W L=-150 \mathrm{~m}, E=10 \mathrm{GPa}, \mathrm{GSI}=75(\mathrm{Y}=26 \mathrm{kN} / \mathrm{m} 3)$

--- WL=-150m, E=70GPa, GSI=75 $(Y=26 \mathrm{kN} / \mathrm{m3})$

$W L=-300 \mathrm{~m}, E=10 \mathrm{GPa}, \mathrm{GSI}=75(\mathrm{Y}=26 \mathrm{kN} / \mathrm{m} 3)$

-.-.-. WL $=-300 \mathrm{~m}, E=70 G P a, G S I=75(Y=26 \mathrm{kN} / \mathrm{m} 3)$ level, static Young's Modulus or GSI. The strength factor is equivalent to factor of safety and is equal to the strength of rock mass over the resultant stresses. It should be stated that in the elastic analysis, when this value is below 1, theoretically, the rock mass will fail, and vice versa (in short-term). The strength factor indicates how close the rock mass is to failure, and hence the rate of change of strength factor is very important to stability sensitivity analysis.

Geometry and Boundary Conditions The shaft dimension is decided based on two mineshafts being operated for minewater heat recovery in the UK. The Hope Shaft in NCMME is ca. $197 \mathrm{~m}$ in depth, while the Markham Colliery No.3 Shaft is ca. $490 \mathrm{~m}$ in depth and $4.6 \mathrm{~m}$ in diameter. In the analysis the shaft has been set to be $400 \mathrm{~m}$ in depth and $4 \mathrm{~m}$ in diameter.

Figure 6 shows a numerical model representing the shaft with different water levels. The model is restrained at the bottom.

The models in Fig. 7 represent the rock mass on the shaft wall with different static Young's Moduli or GSIs simulating the re-injected or thermally-heated minewater. The water level is set at $-50 \mathrm{~m}$.

The model runs (over 350 in total) examine different combinations of the elastic, plastic analyses, static Young's Moduli and GSI changes in the zone od influence for the different rock masses (1-16) and are shown in Table 4. 
Fig. 12 Sigma 1 for a $\mathrm{UCSi}=50 \mathrm{MPa}$ and k-ratio $=0.5$; b UCSi $=200 \mathrm{MPa}$ and k-ratio $=0.5 ;$ c UCSi $=50$ $\mathrm{MPa}$ and k-ratio $=2.0$; d $\mathrm{UCSi}=200 \mathrm{MPa}$ and $\mathrm{k}$-ratio $=2.0$
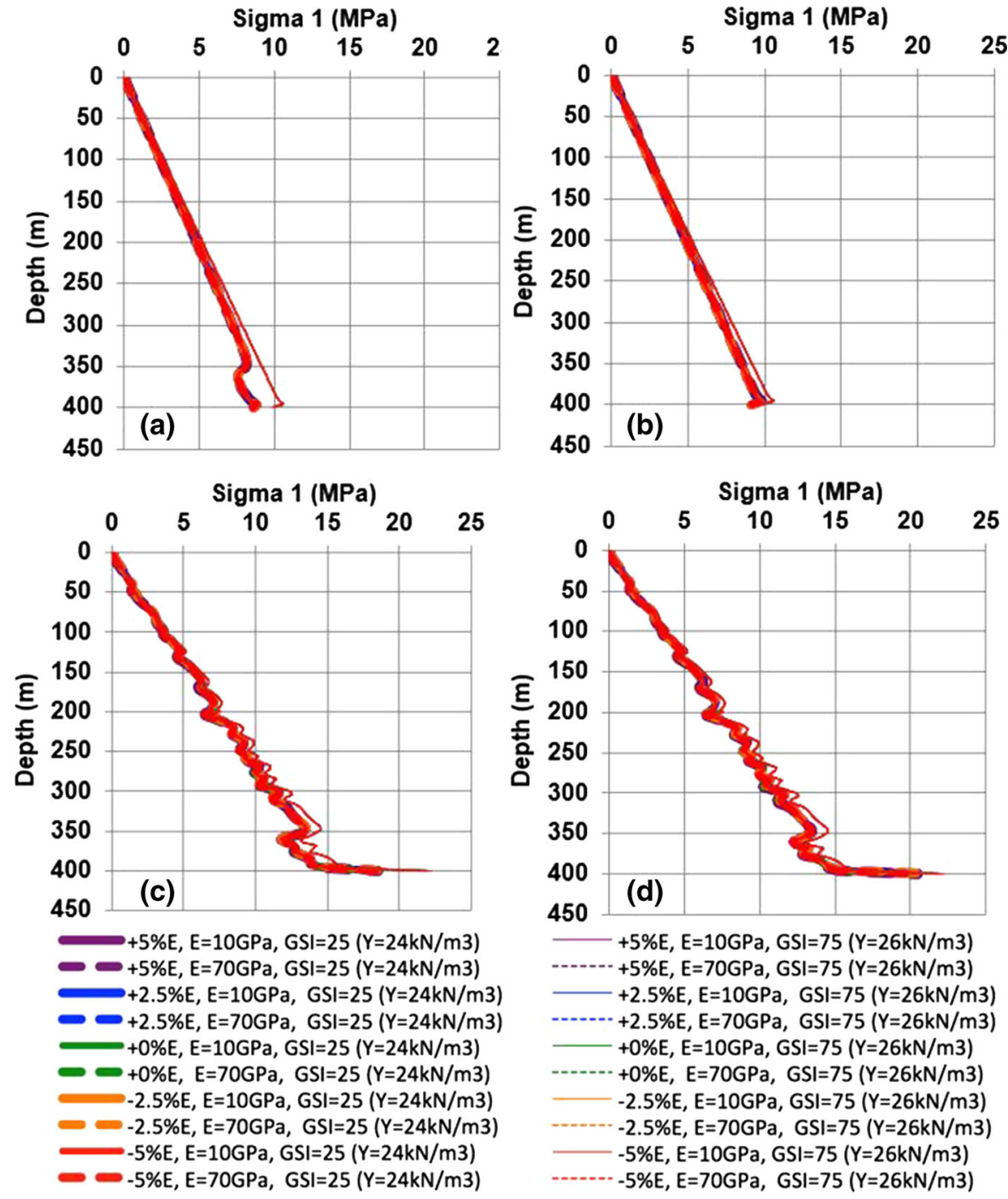

\section{Numerical Results and Discussion}

The results of numerical analysis in $\mathrm{RS}^{2}$ are shown and discussed in this section. Figure 8 shows some examples of sigma 1, total displacement and yielded elements from plastic analyses and strength factor from elastic analyses. A query line with data points of $2 \mathrm{~m}$ interval is drawn on the shaft wall in each analysis to obtain quantitative results. The results of the query lines are represented in graphs of major principal stress, total displacement and strength factor against depth as shown in Sects. 4.1-4.3.

In the following Sects. 4.1-4.3 the thick lines represent GSI of 25, while the thin lines represent GSI of 75. The solid lines represent $\mathrm{Ei}=10 \mathrm{GPa}$, while the dashed lines represent $\mathrm{Ei}=70 \mathrm{GPa}$.

It should be noted that the required strength factor ensuring stability is at 1.5 and threshold vertical lines at strength factors of 1 and 1.5 are drawn on Figs. 11, 14 , and 17. The failure in these examples is simulated to be progressive failure taking into considerations the time-dependent component on the geomechanical behaviour of the rock mass (Paraskevopoulou 2016; Paraskevopoulou et al. 2017, 2018).

\subsection{Changing the Water Level}

Figures 9 and 10 show the Sigma 1 and Total Displacement results of elasto-plastic analyses 
Fig. 13 Total displacement for $\mathbf{a} \mathrm{UCSi}=50 \mathrm{MPa}$ and k-ratio $=0.5$;

b UCSi $=200 \mathrm{MPa}$ and

k-ratio $=0.5$;

c UCSi $=50 \mathrm{MPa}$ and

k-ratio $=2.0$;

d $\mathrm{UCSi}=200 \mathrm{MPa}$ and

k-ratio $=2.0$
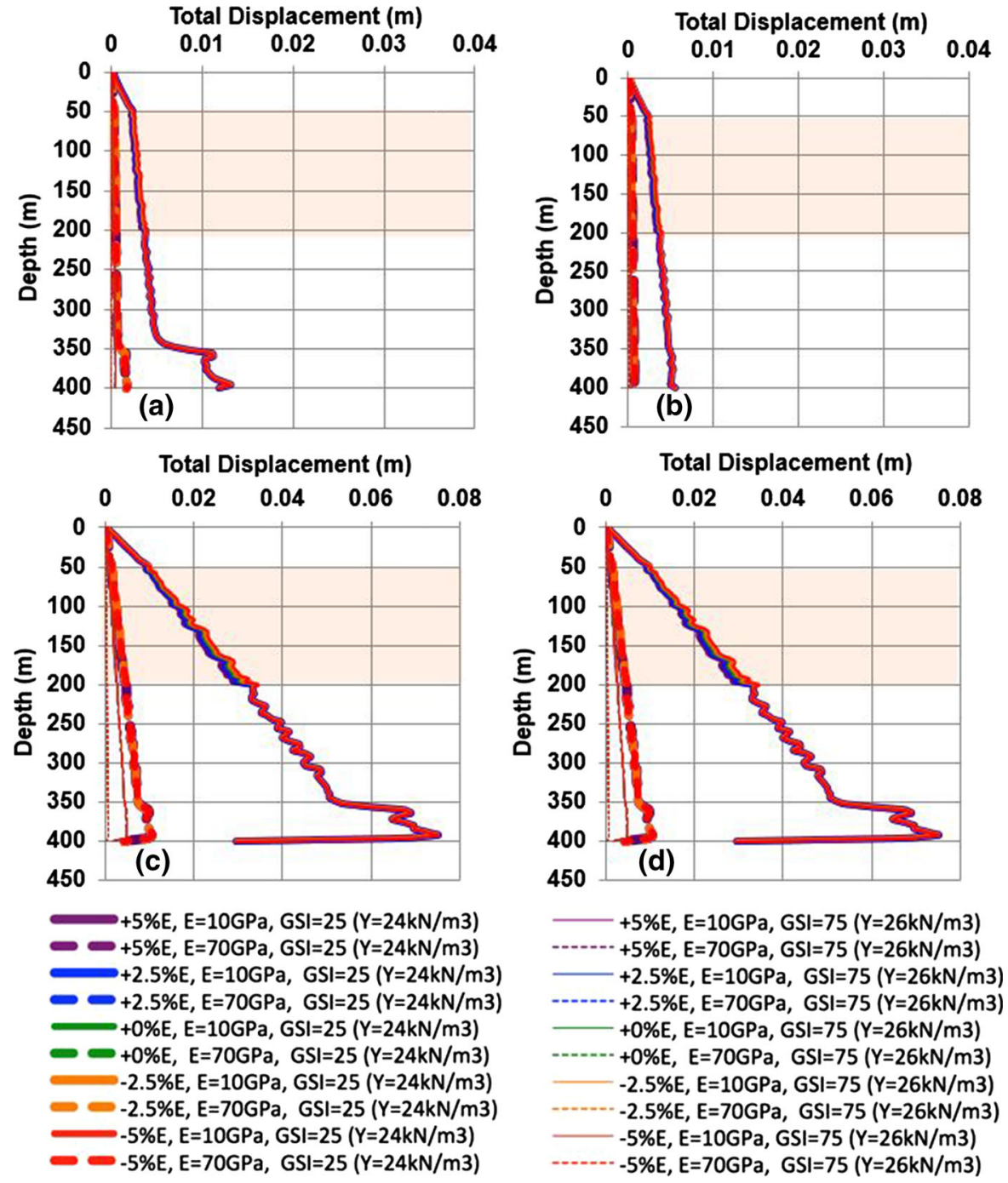

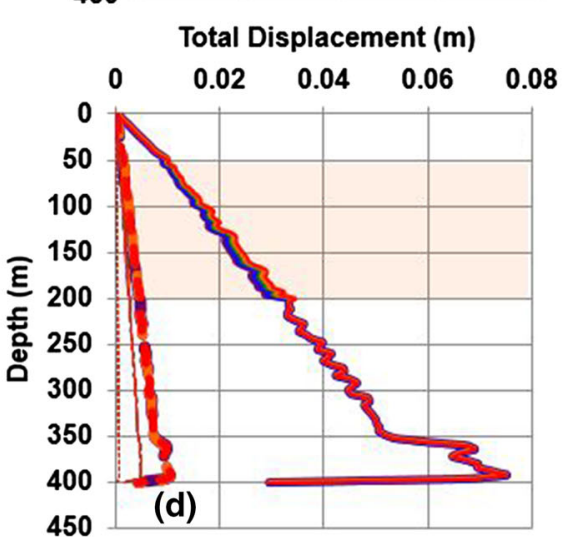

$+5 \% E, E=10 G P a, G S I=75(Y=26 \mathrm{kN} / \mathrm{m} 3)$ $+5 \% E, E=70 G P a, G S I=75(Y=26 \mathrm{kN} / \mathrm{m} 3)$ $+2.5 \% \mathrm{E}, \mathrm{E}=10 \mathrm{GPa}, \mathrm{GSI}=75(\mathrm{Y}=26 \mathrm{kN} / \mathrm{m} 3)$ $+2.5 \% \mathrm{E}, \mathrm{E}=70 \mathrm{GPa}, \mathrm{GSI}=75(\mathrm{Y}=26 \mathrm{kN} / \mathrm{m3})$ $+0 \% E, E=10 \mathrm{GPa}, \mathrm{GSI}=75(\mathrm{Y}=26 \mathrm{kN} / \mathrm{m} 3)$ $+0 \% E, E=70 G P a, G S I=75(Y=26 \mathrm{kN} / \mathrm{m} 3)$ $-2.5 \% E, E=10 \mathrm{GPa}, \mathrm{GSI}=75(\mathrm{Y}=26 \mathrm{kN} / \mathrm{m} 3)$ $-2.5 \% E, E=70 \mathrm{GPa}, \mathrm{GSI}=75(\mathrm{Y}=26 \mathrm{kN} / \mathrm{m} 3)$ $-5 \% E, E=10 G P a, G S I=75(Y=26 k N / m 3)$

$-5 \% \mathrm{E}, \mathrm{E}=70 \mathrm{GPa}, \mathrm{GSI}=75(\mathrm{Y}=26 \mathrm{kN} / \mathrm{m} 3)$ respectively, while Fig. 11 shows the Strength Factor results of the elastic analyses. The red lines represent the water level of $-50 \mathrm{~m}$, green represents $-150 \mathrm{~m}$, and blue represents $-300 \mathrm{~m}$.

General behavioural trends between Fig. 9a, b and those between Fig. 9c, d (i.e. variations in UCSi) show very little differences.

It is observed the red solid and dashed thick lines in Figs. 9a, c and 10a, c, and green solid and dashed thick lines in Figs. 9c and 10c have different patterns to the other lines at the bottom ca. $50 \mathrm{~m}$ of the shaft. This can be explained as the strength factor for these lines in that region is below 1 , these models are yielded as shown in Fig. 11a, c and hence the deviation.
In addition, Fig. 10 shows that the curves deviate from a straight trend line when the depth is below the water level. This is due to the stresses from the water collumn are acting on the shaft wall. However, an increase in water level reduces the total displacement of the shaft wall that is submerged, as shown in Fig. 10. Figure 11 shows that the lowest strength factors of most of the curves for GSI 25 fall within values of 1.5 (especially for k-ratio of 2) and below 1 . The strength factor of the curves also shifts toward 1 as the water table increases. The rate of shift is, in general, higher in k-ratio of 0.5 than in k-ratio of 2.0. This indicates that an increase in water level inside the shaft deteriorates its stability, especially when the major principal stress is in the vertical 
Fig. 14 Strength factor for a $\mathrm{UCSi}=50 \mathrm{MPa}$ and k-ratio $=0.5$; b $\mathrm{UCSi}=200 \mathrm{MPa}$ and k-ratio $=0.5$; c UCSi $=50 \mathrm{MPa}$ and k-ratio $=2.0$; d UCSi $=200 \mathrm{MPa}$ and k-ratio $=2.0$
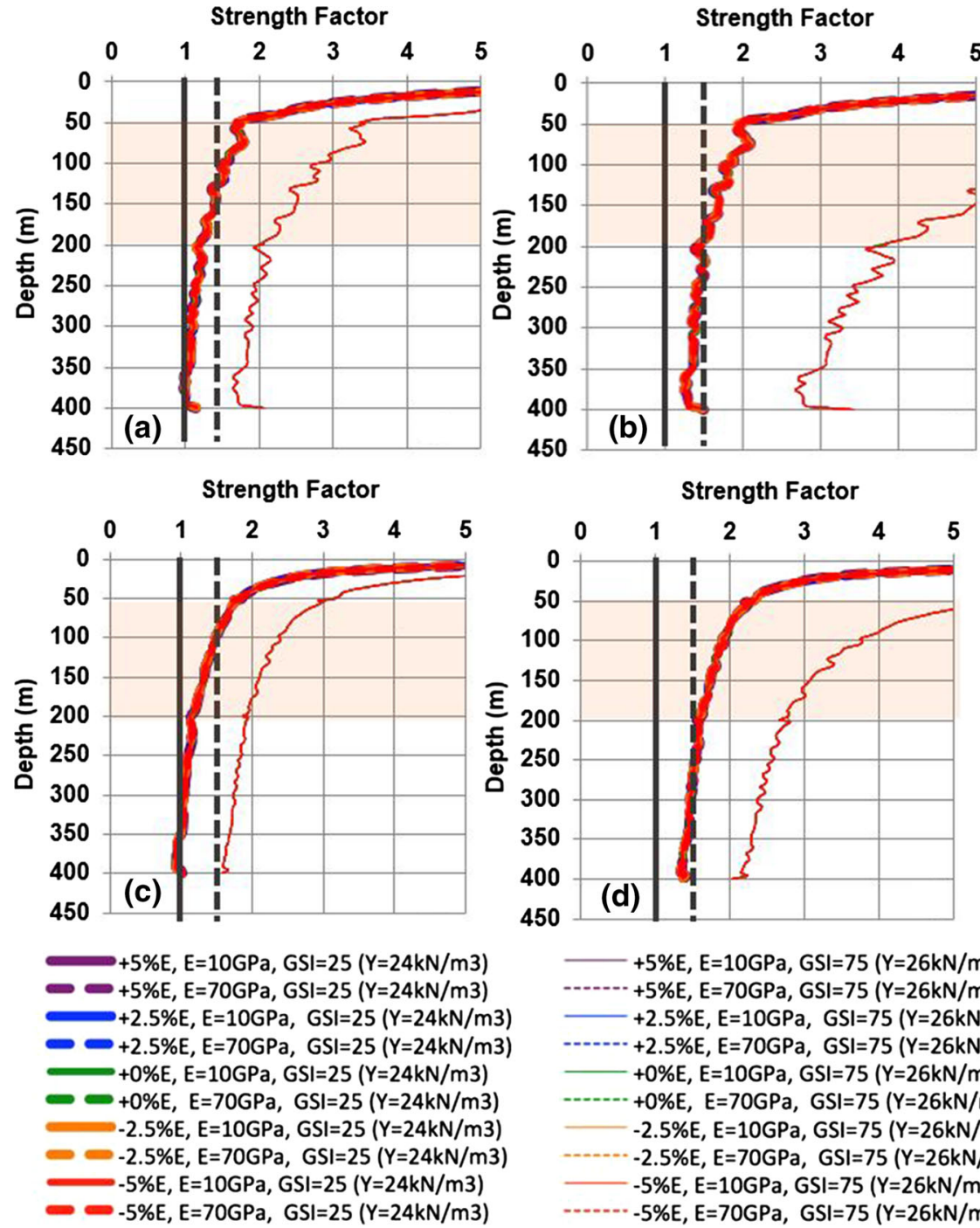

Strength Factor

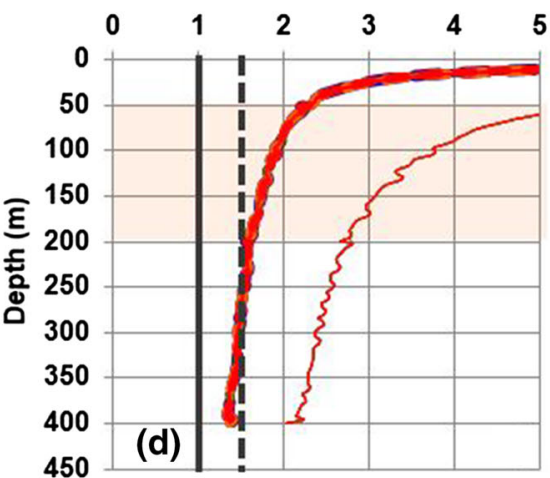

450

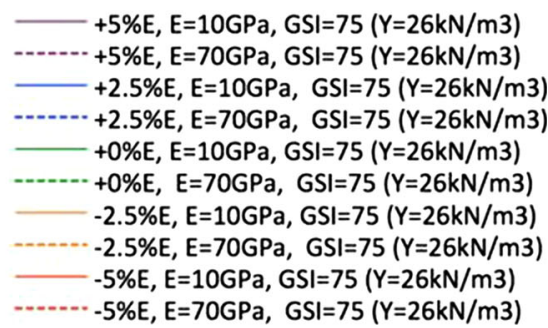

direction. Hence, monitoring of displacement of shaft cannot aid in understanding how close the shaft is to failure. Instead, the direction of major principal stress is more important to be investigated and known.

Figures 9, 10 and 11 show that Sigma 1, total displacement and strength factor are mainly dependent of k-ratios and the water level.

\subsection{Changing the Static Young's Modulus}

Figures 12 and 13 show the results of ealsto-plastic analyses. Figure 14 shows the results of the elastic analyses. The water levels in all the analyses are the same, at -50 m. Furthermore in Figs. 12, 13 and 14 the green lines represent the shaft wall (i.e. orange region in Fig. 7) that has no static Young's Modulus difference with surrounding rock mass (i.e. no temperature difference). The orange lines represent the shaft wall with $-2.5 \%$ lower Ei than the surroundings, indicating a slightly higher temperature. The red lines represent the shaft wall with $-5 \%$ lower Ei than the surroundings, indicating even higher temperature. On the other hand, the blue lines represent the shaft wall with $+2.5 \%$ higher Ei than the surrounding rock mass, indicating a slightly lower temperature. Finally, the purple represent the shaft wall with $+5 \%$ higher Ei than the surrounding, indicating even lower temperature.

Sigma 1 and strength factor in Figs. 12 and 14 show almost no difference with the Ei change of the 
Fig. 15 Sigma 1 for a $\mathrm{UCSi}=50 \mathrm{MPa}$ and k-ratio $=0.5$; b UCSi $=200 \mathrm{MPa}$ and k-ratio $=0.5$; c UCSi $=50 \mathrm{MPa}$ and k-ratio $=2.0$; d UCSi $=200 \mathrm{MPa}$ and $\mathrm{k}$-ratio $=2.0$

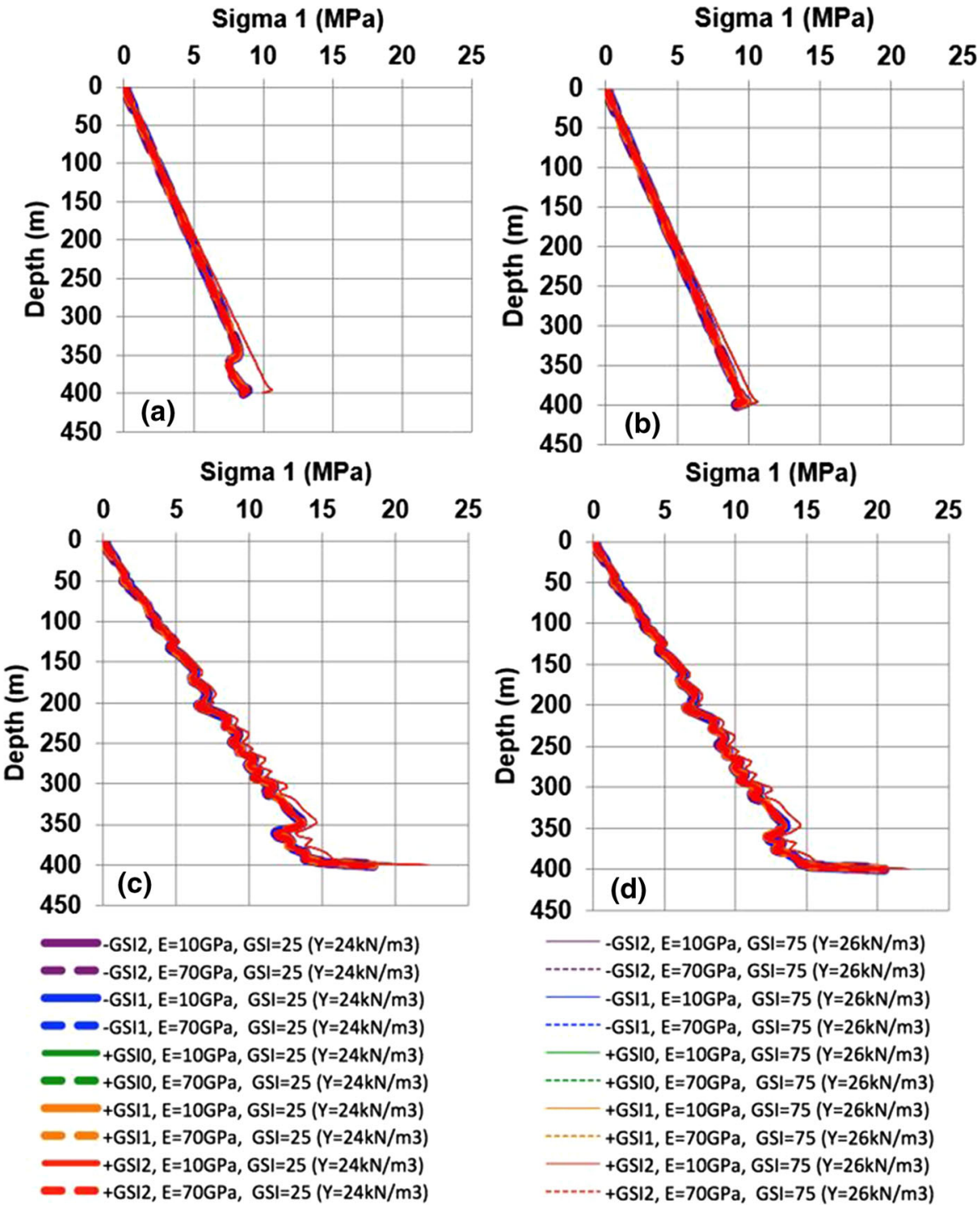

shaft wall but the total displacement Fig. 16 show that in the region with different $\mathrm{Ei}$ (shaded in orange), there is a trend that with temperature increase (Ei increase), the displacement increases. But such change is only bounded in that region.

\subsection{Changing the GSI}

Figures 15 and 16 show the results of the plastic analyses. Figure 17 shows the results of the elastic analyses. The water levels in all the analyses are also the same, at - 50 m. In Figs. 15, 16 and 17 the green lines represent the orange region of shaft wall in Fig. 7 that has no GSI difference with surroundings, i.e. no temperature difference. The orange lines represent the shaft wall with GSI increased by +1 compared to the surroundings, indicating a slightly higher temperature. The red lines represent the shaft wall with GSI increased by +2 compared to the surroundings, indicating even higher temperature. On the other hand, the blue lines represent the shaft wall with GSI decreased by -1 compared to the surroundings, indicating a slightly lower temperature. And lastly, the purple represent the shaft wall with GSI decreased by -2 .

Unlike the results in Sect. 4.1, the total displacement in Fig. 16 shows that in the "orange region", there is a trend that with increasing temperature 
Fig. 16 Total displacement for $\mathbf{a} \mathrm{UCSi}=50 \mathrm{MPa}$ and k-ratio $=0.5$; b $\mathrm{UCSi}=200 \mathrm{MPa}$ and k-ratio $=0.5$; c UCSi $=50 \mathrm{MPa}$ and k-ratio $=2.0 ; \mathbf{d}$ UCSi $=200$ $\mathrm{MPa}$ and k-ratio $=2.0$

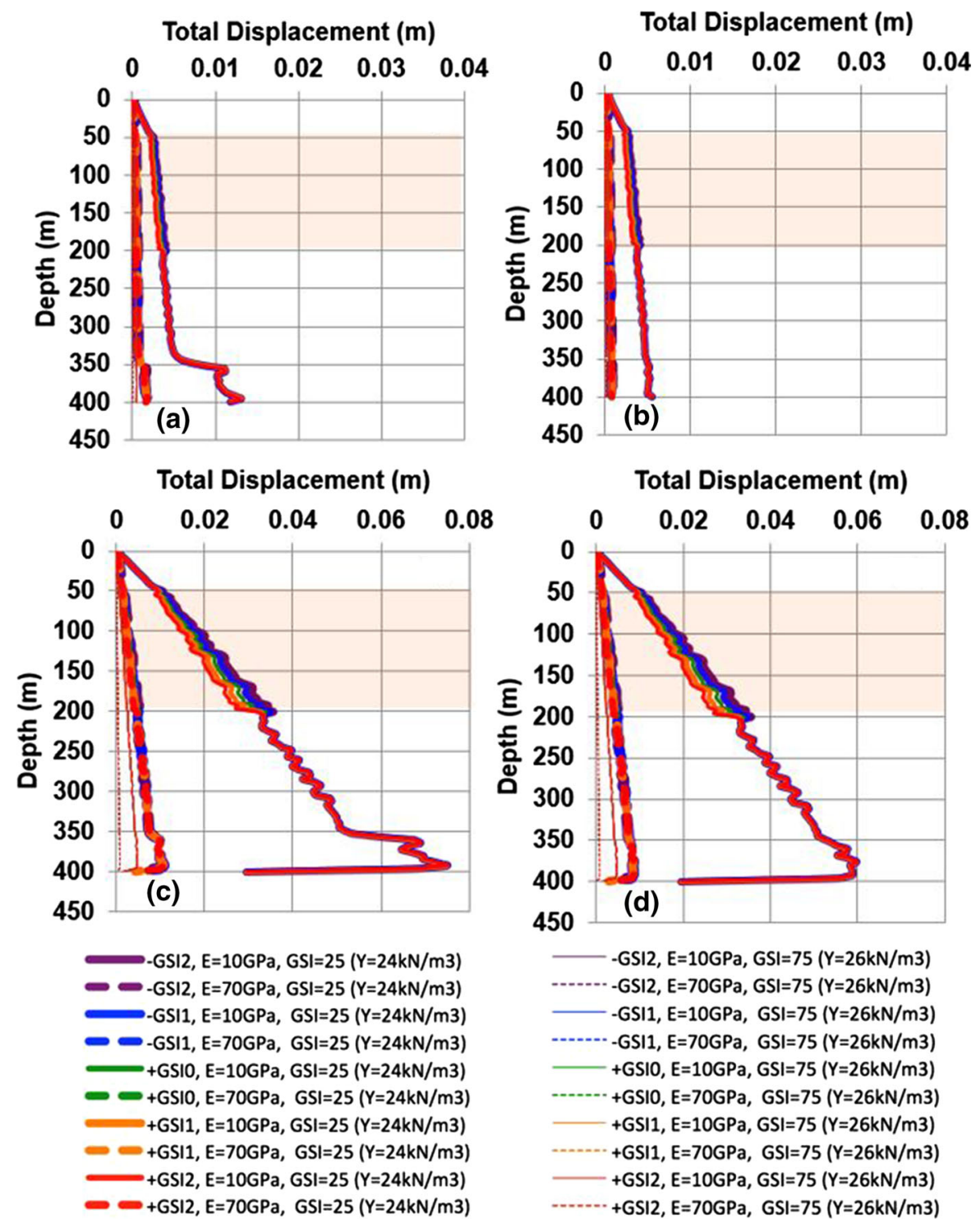

(increasing GSI), the displacement decreases. However, as mentioned, there is no quantitative relationship between temperature and GSI, it is therefore not known whether the effect of GSI or the effect of static Young's Modulus is greater in total displacement. Furthermore, the strength factor Fig. 17 shows that there is a trend that with decreasing temperature (decreasing GSI), the shaft is closer from failure, with some parts of the curve in the "orange region" falling below value of 1.5. But such changes are also only bounded in that region. The area outside the "orange region" is not affected.
Such findings show that the temperature of the water re-injecting into the same shaft in the standing column system and that of the heat exchanger tube that is put in mineshaft in closed-loop system should not be for temperatures lower than the temperature of the shaft wall, as it can deteriorate the stability of the shaft. But as the quantitative relationship between temperature and GSI is not known, the findings of this research work can be used to further find the limit of temperature contrast while keeping the shaft stable.

The results of Sigma 1 when k-ratio is 2 and all results of total displacement and strength factor clearly show variations with depth. The reason for such 
Fig. 17 Strength factor for a $\mathrm{UCSi}=50 \mathrm{MPa}$ and k-ratio $=0.5$; b UCSi $=200 \mathrm{MPa}$ and k-ratio $=0.5$; c $\mathrm{UCSi}=50 \mathrm{MPa}$ and k-ratio $=2.0$; d UCSi $=200 \mathrm{MPa}$ and k-ratio $=2.0$
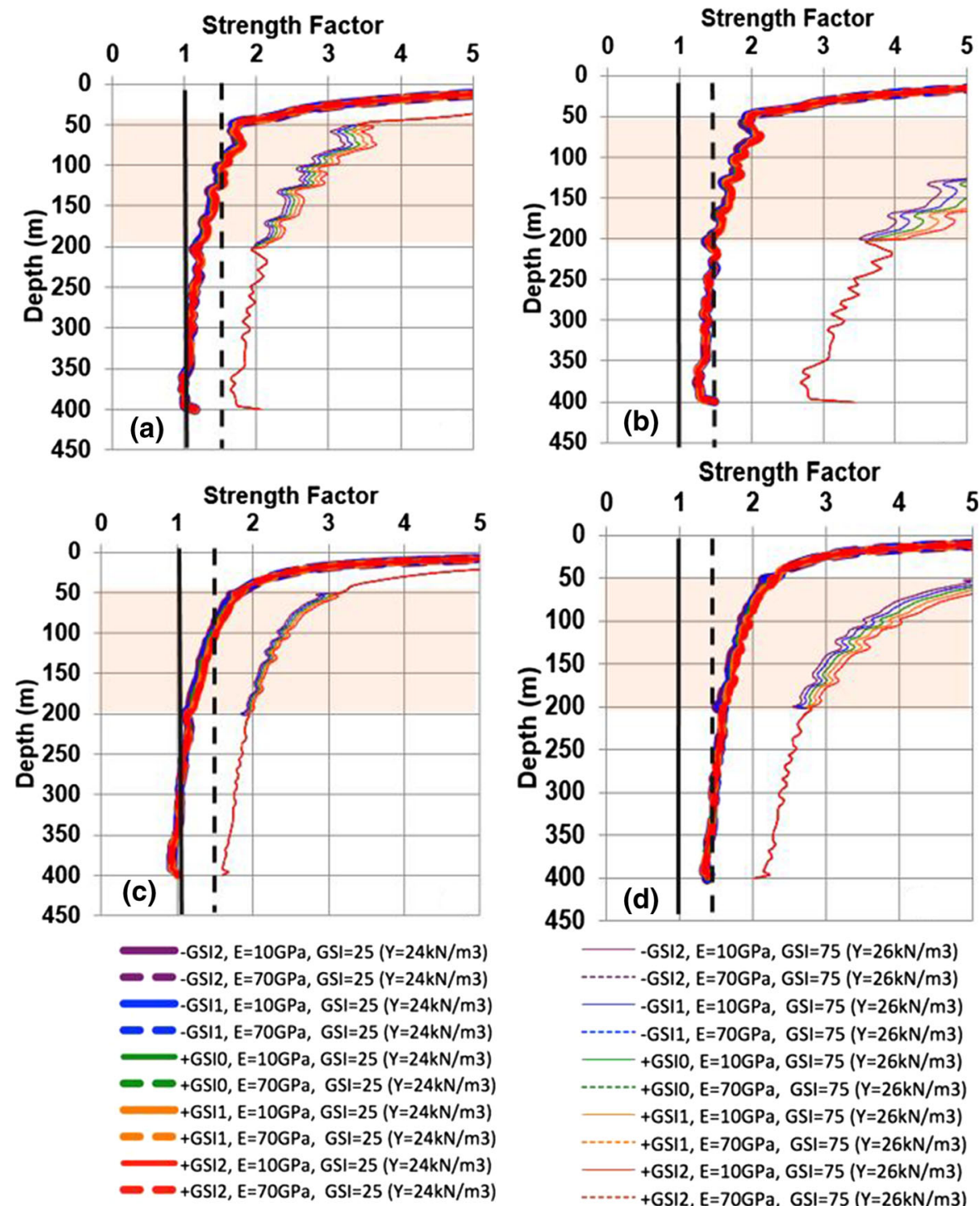

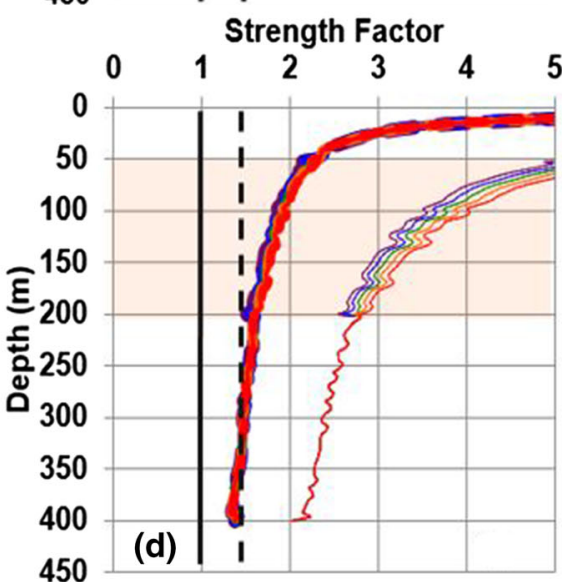

450

$-G S I 2, E=10 G P a, G S I=75(Y=26 \mathrm{kN} / \mathrm{m} 3)$ $-G S I 2, E=70 G P a, G S I=75(Y=26 \mathrm{kN} / \mathrm{m} 3)$ -GSI1, E=10GPa, GSI $=75(Y=26 \mathrm{kN} / \mathrm{m} 3)$ $-G S I 1, E=70 G P a, G S I=75(Y=26 \mathrm{kN} / \mathrm{m} 3)$ $+\mathrm{GSIO}, E=10 \mathrm{GPa}, \mathrm{GSI}=75(\mathrm{Y}=26 \mathrm{kN} / \mathrm{m} 3)$ $+\mathrm{GSIO}, E=70 \mathrm{GPa}, \mathrm{GSI}=75(\mathrm{Y}=26 \mathrm{kN} / \mathrm{m} 3)$ $+\mathrm{GSI}, \mathrm{E}=10 \mathrm{GPa}, \mathrm{GSI}=75(\mathrm{Y}=26 \mathrm{kN} / \mathrm{m} 3)$ $+\mathrm{GSI}, \mathrm{E}=70 \mathrm{GPa}, \mathrm{GSI}=75(\mathrm{Y}=26 \mathrm{kN} / \mathrm{m} 3)$ $+\mathrm{GSI} 2, \mathrm{E}=10 \mathrm{GPa}, \mathrm{GSI}=75(\mathrm{Y}=26 \mathrm{kN} / \mathrm{m} 3)$ $+\mathrm{GSI} 2, \mathrm{E}=70 \mathrm{GPa}, \mathrm{GSI}=75(\mathrm{Y}=26 \mathrm{kN} / \mathrm{m} 3)$ phenomenon can be explained by the direction of displacement shown in Figs. 18 and 19.

As stress increases with depth, the axial compression and lateral expansion of the elements at different depths are different. However, in a continuum model, the elements must be in contact with one another. There are induced-stresses at different depths, resulting in displacement changes at different depths, especially in low k-ratio cases. The variation in inclination of displacement (Figs. 10, 13, 16) is higher in low k-ratio is due to relation between the direction of major principal stress and the surface, where movement is allowed. In the shaft, the surface that allows movement is the vertical wall. When the major principal stress is also vertical (when k-ratio is lower than 0.5 ) the variation of displacement will be higher in a continuum model.

\subsection{Estimating the Influence Zone-Orange Zone}

After performing the sensitivity analyses described in the previous sections, it is discovered that the effect of the different static Young's Modulus or GSI at certain parts of the shaft wall in regards to total displacement and strength factor is only limited in that area (i.e. orange shaded region in the graphs). Therefore, the 

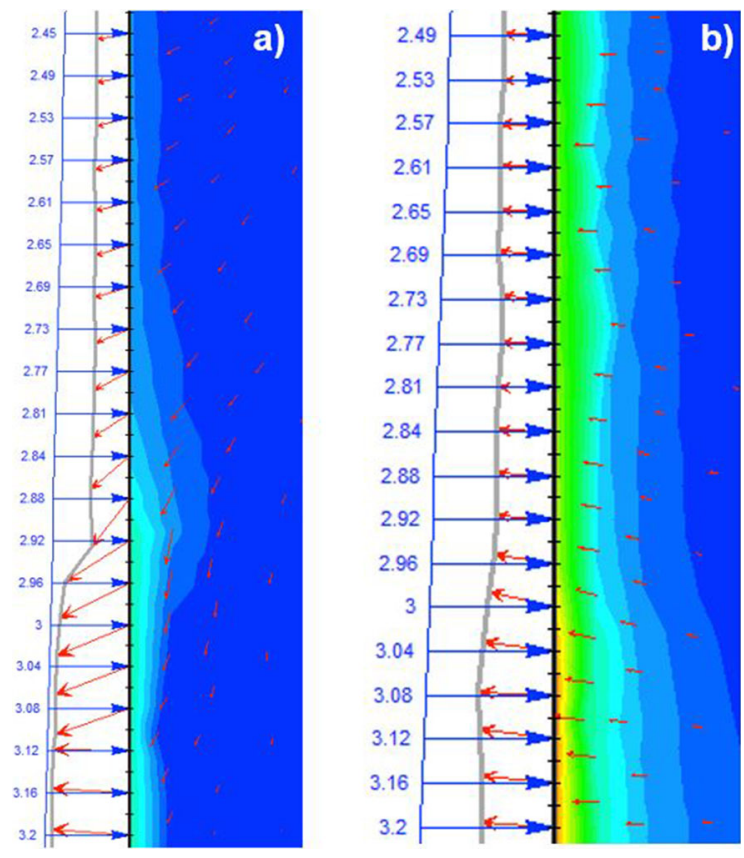

Fig. 18 Zoomed total displacement results of plastic analysis in water level $=-50 \mathrm{~m}, \mathrm{GSI}=25, \gamma=24 \mathrm{kN} / \mathrm{m}^{3}, \mathrm{UCSi}=50$ $\mathrm{MPa}$ and $\mathrm{Ei}=10 \mathrm{GPa}$ : a k-ratio $=0.5$ (red arrows are of scale factor 5000) and $\mathbf{b}$ k-ratio $=2.0$ (red arrows are of scale factor 100)

impact of the extent of the influence zone has been further analyzed: thicknesses ranging from $10 \mathrm{~m}$, $20 \mathrm{~m}$ and $30 \mathrm{~m}$. However, the results show no difference in Sigma 1, total displacement and strength factor as shown in Fig. 20 for the two k-ratios k $=0.5$ and $\mathrm{k}=2.0$ for one of the models (UCSI $=50 \mathrm{MPa}$ and $\left.\mathrm{E}_{\mathrm{i}}=10 \mathrm{GPa}, \mathrm{GSI}=25\right)$. As the length of the "orange zone" directly relates to the area of change in total displacement and the strength factor, it is suggested temperature and displacement monitoring of the shaft wall at different depths to delineate the "orange zone" to be used.

\subsection{Possible Failure at Markham No.3 Shaft, Derbyshire, UK}

The minewater heat recovery operation at the No.3 Shaft in Markham's Colliery is one of those using standing column configuration. As per Healeyhero (2015) and Banks et al. (2017), the shaft is $4.6 \mathrm{~m}$ in diameter and ca. $490 \mathrm{~m}$ in depth, with brick as lining. The mine started its operation in 1904 and was abandoned in 1993. In 2012, the water level was at
$235 \mathrm{mbgl}$ (Athresh et al. 2015; Burnside et al. 2016b; Banks et al. 2017). In January 2015, as the minewater level had risen, the pump was re-positioned at $170 \mathrm{mbgl}$ and the reinjection was at $153 \mathrm{mbgl}$ (Burnside et al. 2016b; Banks et al. 2017). In February 2016, the water level had risen to $136 \mathrm{mbgl}$ (Banks et al. 2017), which implies there is a ca. $354 \mathrm{~m}$ of water column in the shaft (Fig. 21).

According to the borehole records from BGS (BGS Ref: SK47SW60, SK47SE46, SK47SE45, SK47SE43, SK47SE60), the geology is mainly interbedded mudstone, siltstone, sandstone, and the Waterloo Coal Seams. By referring to the geological map by BGS as shown in Fig. 21b the region is deformed with folding and extensive faulting. Thus, the GSI of the rock mass in the area is expected to be within the range of only 20-30 (heavily sheared material).

From the results shown in Sect. 4.1, a water column of $350 \mathrm{~m}$ high (with peak GSI 25, UCSi of around $50 \mathrm{MPa}, \mathrm{k}$-ratio of 0.5 or 2.0 and without shaft lining) will cause damage and progressively lead to failure of the base of the shaft. This means if the rock mass at No.3 Shaft of Markham Colliery has the average UCSi of around $50 \mathrm{MPa}$, typical value for sedimentary rock (Marinos and Tsiambaos 2010) and k-ratio of 0.5 or 2.0, and the shaft lining has been deteriorated (which is highly possible), the base of the shaft has already been failed or ruptured or is currenlty very close to failure. As the water level is expected to keep rising (Banks et al. 2017), the failure zone will expand upward and may eventually block the mine galleries that feed the heated minewater to the mineshaft during heat recovery.

As the temperature of minewater returning to the shaft is only up to $3{ }^{\circ} \mathrm{C}$ lower than the minewater (Burnside et al. 2016b; Banks et al. 2017), it is expected that such small decrease in temperature will not decrease the strength factor at the top part of the shaft wall.

\section{Concluding Remarks}

During minewater heat recovery, from a geological engineering perspective, the shaft has to be structurally stable in the long-term. In some shafts, the water level keeps rising. Additionally, in some configurations during operation, the temperature of the surrounding rock mass can vary. Consequently, the 
Fig. 19 Explanation of the inclination of displacement and effect of water

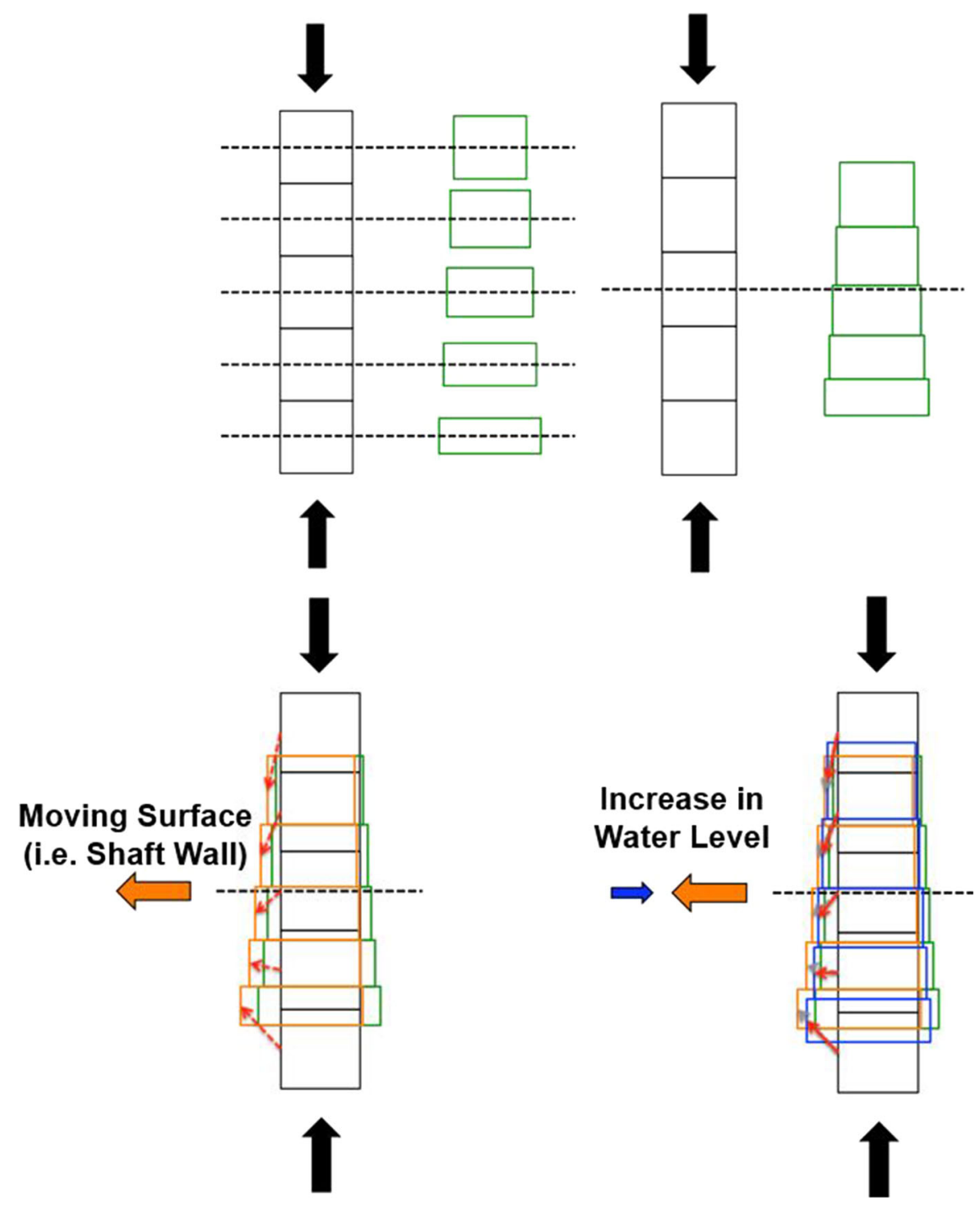

effect of water level and temperature changes has to be taken into consideration and analyzed. As temperature is not a parameter used to describe the rock mass quality, the correlation between certain rock mass properties and temperature is required. It is found that, in general, as the static Young's Modulus decreases and the rock joint roughness expressed by changing GSI increases with increasing temperature in the range of ca. $5-30{ }^{\circ} \mathrm{C}$. Sensitivity analyses are therefore performed by changing water level, changing the static Young's Modulus only or GSI within the influence zone of the wall shaft.

From the sensitivity analysis the following conclusions can be derived:
With increasing the water level, the whole shaft will be less stable, which is shown by a decrease in strength factor of the whole shaft. Below the water level, due to the effective stresses, the rate of increase in total displacement with increasing depth reduces. The total displacement should not be used as a monitor of whether the shaft wall is close to instabilities. The decrease rate of the strength factor (due to increase of water level) varies at different depths of the shaft.

By changing the static Young's Modulus partially, the strength factor remains unaffected. The total displacement increases with decrease in static Young's Modulus (i.e. increase in temperature). Such change is only confined by the region of the shaft wall 

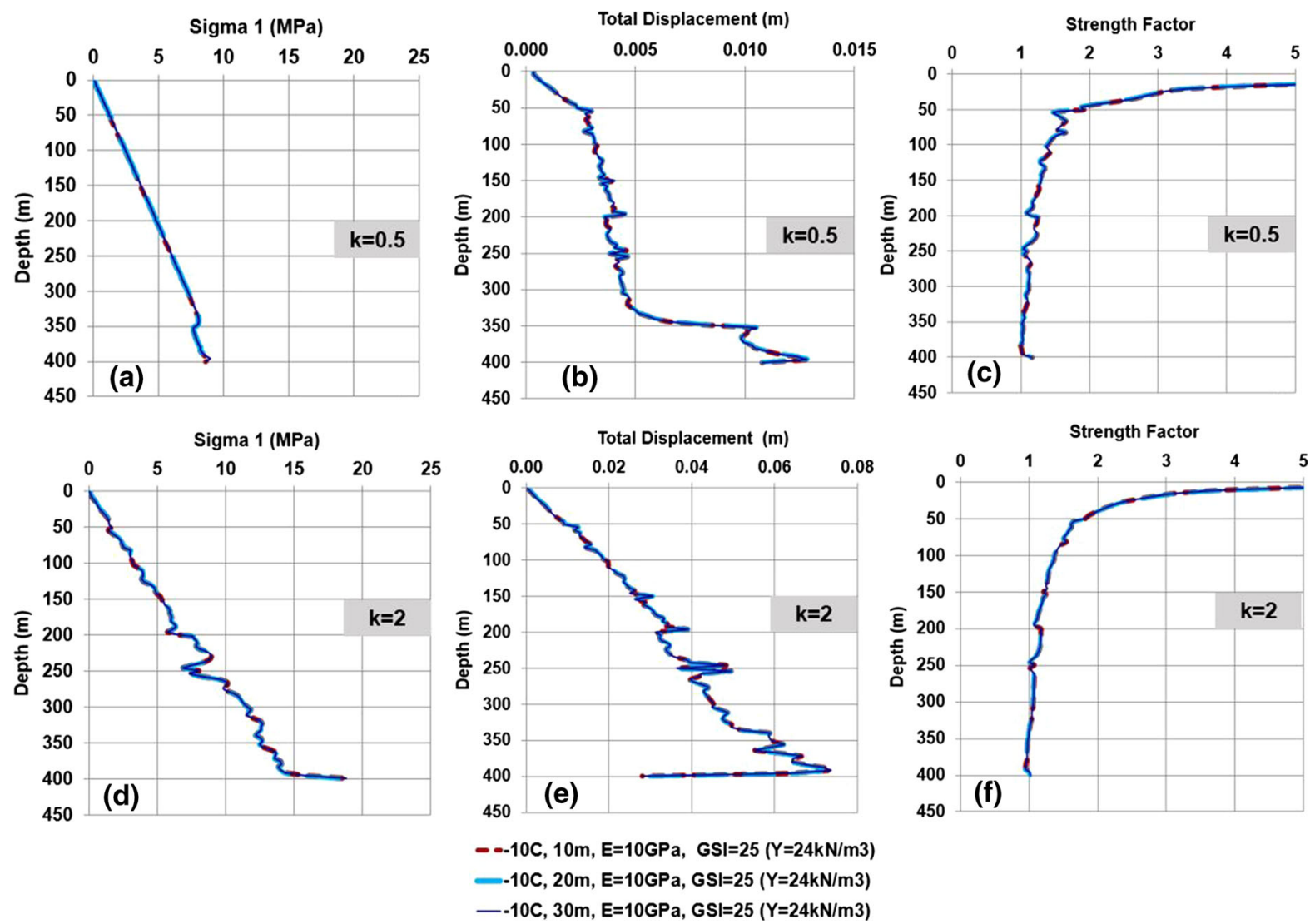

$-10 \mathrm{C}, 20 \mathrm{~m}, \mathrm{E}=10 \mathrm{GPa}, \mathrm{GSI}=2$

$-10 \mathrm{C}, 30 \mathrm{~m}, \mathrm{E}=10 \mathrm{GPa}, \mathrm{GSI}=25(\mathrm{Y}=24 \mathrm{kN} / \mathrm{m} 3)$

Fig. $20 \mathrm{UCSi}=50 \mathrm{MPa}$ and k-ratio $=0.5$ : a Sigma 1; b Total Displacement; $\mathbf{c}$ Strength Factor; and UCSi $=50 \mathrm{MPa}$ and k-ratio = 2.0: d Sigma 1; e Total Displacement; and f Strength Factor

("orange region"). The rate of increase in total displacement increases as the static Young's Modulus decreases (i.e. temperature increases).

The total displacement decreases with increase in GSI (i.e. increase in temperature). Such change is also only confined in the "orange region". The rate of decrease in total displacement decreases as the GSI increases (i.e. temperature gets higher). The strength factor (only in "orange region") decreases with decrease in the GSI due to cooler re-injected minewater. The rate of decrease in strength factor decreases as the depth increases. Such rate of decrease is more or less constant at the same depth if the strength of surrounding rock mass does not change.

By comparing the results of the sensitivity analyses of static Young's Modulus and GSI, it is found that the effect of static Young's Modulus becomes more and more dominant as temperature increases, while that of GSI decreases. As there is no quantitative correlation between the joint roughness and the stability factors, the findings in this research work are recommended to be used until such quantitative correlation is established.

It is suggested when open-loop systems or closedloop system are selected the heat exchanger should be placed in a minewater treatment pond (but not in the mineshaft). Standing column systems should only be used when the water level is not rising, and the reinjection should be positioned at the top of the water column inside the shaft.

The length of the "orange zone" directly relates to the area of the total displacement and strength factor changes. This length should be obtained by measuring and monitoring the temperature variations of the shaft wall at different depths.

In summation, an increase in the water level deteriorates the stability of the shaft, partial changes in the static Young's Modulus do not impact the overall stability only the zone of influence ("orange region"), whereas when the GSI increases the shaft becomes more stable. 


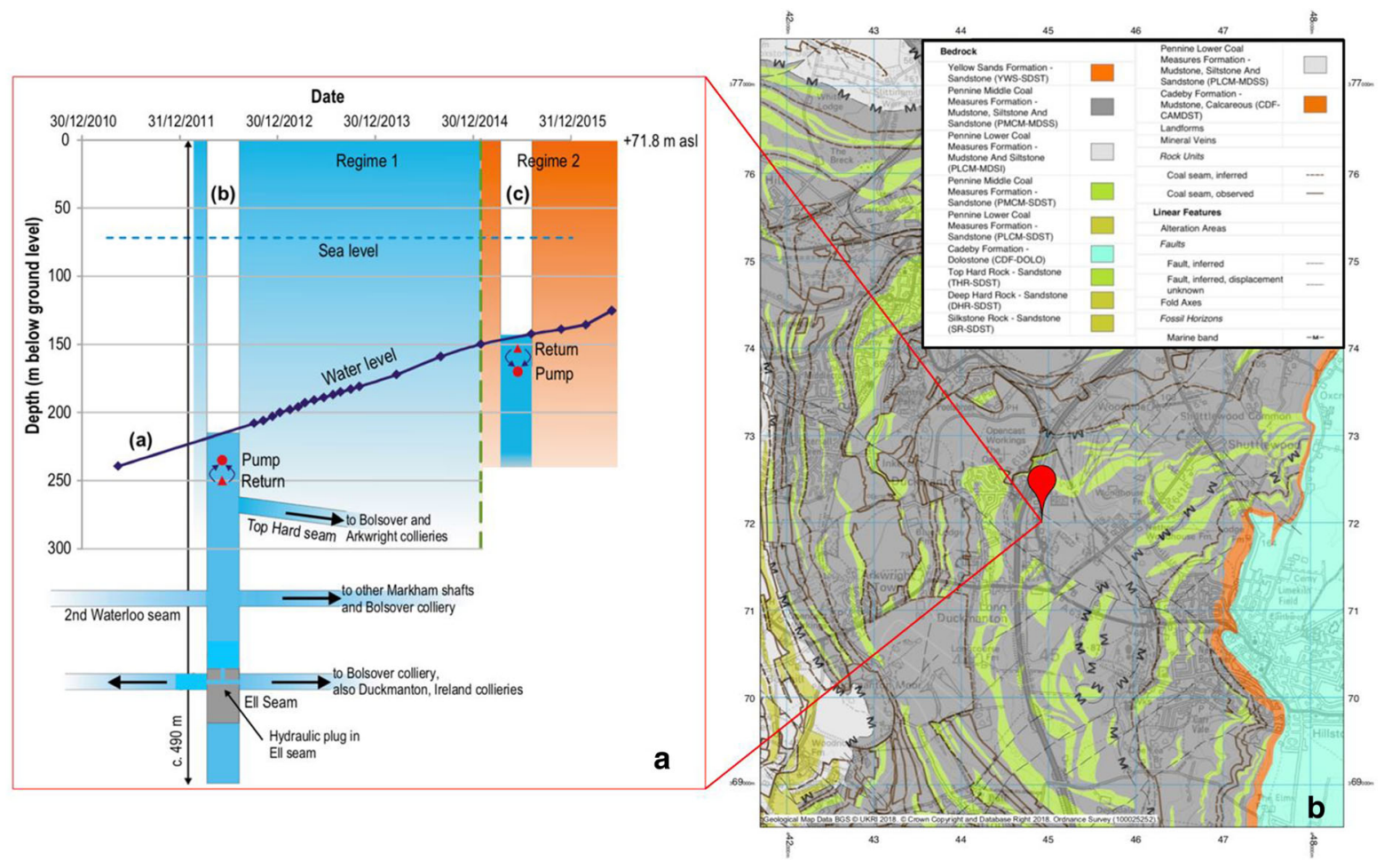

Fig. 21 a Simplified cross-section of Markham No.3 Shaft with results of water level monitoring (Banks et al. 2017) and b geological map and position of Markham No.3 Shaft (scale 1:50,000) (BGS and Digimap 2018)

Acknowledgements The authors would like to acknowledge Mr. Andy Smith from National Coal Mining Museum of England for his guided tour at the Caphouse Colliery who provided a lot of useful information on the operation of minewater heat recovery.

Open Access This article is distributed under the terms of the Creative Commons Attribution 4.0 International License (http:// creativecommons.org/licenses/by/4.0/), which permits unrestricted use, distribution, and reproduction in any medium, provided you give appropriate credit to the original author(s) and the source, provide a link to the Creative Commons license, and indicate if changes were made.

\section{References}

Athresh AP, Al-Habaibeh A, Parker K (2015) Innovative approach for heating of buildings using water from a flooded coal mine through an open loop based single shaft GSHP system. Energy Proc 75:1221-1228

Banks D (2012) An introduction to thermogeology: ground source heating and cooling, 2nd edn. Wiley, Chichester, p 526

Banks D (2016) Making the red one green-renewable heat from abandoned flooded mines. In: Proceedings 36th annual groundwater conference, Tullamore, Ireland
Banks D, Athresh A, Al-Habaibeh A, Burnside N (2017) Water from abandoned mines as a heat source: practical experiences of open- and closed-loop strategies, United Kingdom. Sustain Water Resour Manag

Brotons V, Tomás R, Ivorra S, Grediaga A, Martínez-Martínez J, Benavente D, Gómez-Heras M (2015) Improved correlation between the static and dynamic elastic modulus of different types of rocks. Mater Struct 2016(49):3021-3037

Burnside NM, Banks D, Boyce AJ (2016a) Sustainability of thermal energy production at the flooded mine workings of the former Caphouse Colliery, Yorkshire, United Kingdom. Int J Coal Geol 164:85-91

Burnside NM, Banks D, Boyce AJ, Athresh A (2016b) Hydrochemistry and stable isotopes as tools for understanding the sustainability of thermal energy production from a 'standing column' heat pump system: Markham Colliery, Bolsover, Derbyshire, UK. Int J Coal Geol 165:223-230

BGS, Digimap (2018) Geological map at Markham

Cai M, Kaiser PK, Tasaka Y, Minami M (2007) Peak and residual strengths of jointed rock masses and their determination for engineering design. In: Eberhardt E, Stead D, Morrison T (eds) Rock mechanics: meeting society's challenges and demands

Domenico PA, Schwartz FW (1998) Physical and chemical hydrogeology. Wiley, Hoboken

Foster SM, Parker K, Banton C, Widdowson S, Bexon R, Godfrey B, Hudson J, Tyler A, Faull ML, Bottomley E (2005) Integrated water management in former coal mining regions guidance to support strategic planning. MIRO 
Gercek H (2007) Poisson's ratio values for rocks. Int J Rock Mech Min Sci 44(2007):1-13

Gertsch RE, Bullock RL (1998) Techniques in underground mining: selections from underground mining methods handbook. Society of mining, metallurgy, and Exploration littleton, $\mathrm{CO}$

Healeyhero (2015) Markham Colliery-1973. Background information - the Colliery. Healeyhero. http://www. healeyhero.co.uk/rescue/pits/markham/markham_73_1. html. Accessed 17 July 2018

Hiddes L, Stefens J, Verhoeven R, Dix M, Eijdems H (2016) The Netherlands. Smart Energy Region

Hoek E (2006) Practical rock engineering In: Course notes. University of Toronto Publications

Hoek E, Marinos P (2000) GSI—a geological friendly tool for rock mass strength estimation. In: Proceedings of GeoEng2000 conference, Melbourne

Hustrulid WA, Bullock RL (2001) Underground mining methods: engineering fundamental and international case studies. Society of Mining, Metallurgy and Exploration Inc., Englewood

Jardón S, Ordóñez MA, Álvarez R, Cienfuegos P, Loredo J (2013) Mine water for energy and water supply in the Central Coal Basin of Asturias (Spain). Mine Water Environ 32:139-151

Kamoshida N, Okawara M, Saito T (2018) Influence of pore water on the mechanical properties of water-saturated rock under very low temperature. J Soc Mater Sci Japan 67(3):330-337

Khan MM, Krige GJ (2002) Evaluation of the structural integrity of aging mine shafts. Eng Struct 24:901-907

Lagny C (2014) The emission of gases from abandoned mines: role of atmospheric pressure changes and air temperature on the surface. Environ Earth Sci 71(2):923-999

Lecomte A, Salmon R, Yang W, Marshall A, Purvis M, Prusek S, Bock S, Gajda L, Dziura J, Niharra AM (2014) Case studies and analysis of mine shafts incidents in Europe. 3. In: International conference on shaft design and Construction (SDC 2012), Apr 2012, London, United Kingdom, 2012

Loredo J, Ordóñez A, Jardón S, Álvarez R (2011) Mine water as geothermal resource in Asturian coal mining basins (NW Spain). In: Rüde RT, Freund A, Wolkersdorfer C (eds) Proceedings of IMWA congress 2011 (Aachen, Germany), mine water managing the challenges, pp 177-181

Macnab JD (2011) A review of the potential thermal resource in Glasgow's abandoned coal mine workings. In: MSc Thesis. University of Strathclyde Publications

Marinos P, Tsiambaos G (2010) Strength and deformability of specific sedimentary and ophiolitic rocks. Bulletin of the Geological Society of Greece. In: Proceedings of 12th international congress

Martin CD (1997) Seventeenth canadian geotechnical colloquium: the effect of cohesion loss and stress path on brittle rock strength. Can Geotech J 34(5):698-725

Ordóñez A, Jardón S, Álvarez R, Andrésa C, Pendása F (2012) Hydrogeological definition and applicability of abandoned coal mines as water reservoirs. J Environ Monit $14: 2127-2136$
Palmer J, Cooper I (2013) United Kingdom housing energy fact file 2013. Department of Energy \& Climate Change Publications

Paraskevopoulou C (2016) Time-dependency of rocks and implications associated with tunnelling

Paraskevopoulou C, Perras M, Diederichs MS, Löw S (2017) The three stages of stress-relaxation-observations for the long-term behaviour of rocks based on laboratory testing. J Eng Geol 216:56-75. https://doi.org/10.1016/j.enggeo. 2016.11.010

Paraskevopoulou C, Perras M, Diederichs MS, Löw S, Lam T, Jensen M (2018) Time-dependent behaviour of brittle rocks based on static load laboratory testing. J Geotech Geol Eng 36:337. https://doi.org/10.1007/s10706-0170331-8

Parker K (2011) Potential for heat pumps in Yorkshire and the rest of the United Kingdom. In: Faull ML (eds) Heat-pump technology using minewater, pp 32-42

Salmon R, Marshall A, Bock S, Madrza A, Rapp S, MuñosNiharra A, Bedford M (2015) Mine shafts: improving security and new tools for the evaluation of risks (MISSTER). European Commission

Sattler T, Paraskevopoulou C (2019) Implications on characterizing the extremely weak sherwood sandstone: case of slope stability analysis using SRF at two oak quarry in the UK. Geotech Geol Eng 37(3):1897-1918

Suknev SV (2016) Determination of elastic properties of rocks under varying temperature. J Min Sci 52(2):378-387

Vakili A, Albrecht J, Sandy M (2014) Rock strength anisotropy and its importance in underground geotechnical design. In: Ausrock 2014: third Australasian ground control in mining conference/Sydney, NWS

Walton G, Kim E, Sinha S, Sturgis G, Berberick D (2018) Investigation of shaft stability and anisotropic deformation in a deep shaft in Idaho, United States. Int J Rock Mech Min Sci 105(2018):160-171

Wang J, Niu D, Zhang Y (2015) Mechanical properties, permeability and durability of accelerated shotcrete. Constr Build Mater 95:312-328

Woodman, J, Ougier-Simonin A, Murphy W, Thomas ME (2018) Thermal effects on discontinuity behaviour: a laboratory scale study. In Proceedings of the 52nd US rock mechanics/geomechanics symposium, 17-20 June, Seattle, Washington

Yang W, Marshall AM, Wanatowski D, Stace LR (2017) An experimental evaluation of the weathering effect on mine shaft lining materials. Adv Mater Sci Eng. https://doi.org/ 10.1155/2017/4219025

Younger PL (2016) A simple, low-cost approach to predicting the hydrogeological consequences of coalfield closure as a basis for best practice in long-term management. Int J Coal Geol 164:25-34

Publisher's Note Springer Nature remains neutral with regard to jurisdictional claims in published maps and institutional affiliations. 